\title{
NONPROFIT SECTOR AND PART-TIME WORK: AN ANALYSIS OF EMPLOYER-EMPLOYEE MATCHED DATA OF CHILD CARE WORKERS
}

\author{
H. Naci Mocan \\ Erdal Tekin \\ Working Paper 7977 \\ http://www.nber.org/papers/w7977 \\ NATIONAL BUREAU OF ECONOMIC RESEARCH \\ 1050 Massachusetts Avenue \\ Cambridge, MA 02138 \\ October 2000
}

\begin{abstract}
We thank Damba Lkhagvasuren, Paul Niemann and Kaj Gittings for excellent research assistance, and Brian Duncan for providing the Census data. Mocan gratefully acknowledges financial support through an NBER Nonprofit Sector Research Grant. The views expressed in this paper are those of the authors and not necessarily those of the National Bureau of Economic Research.

(C) 2000 by H. Naci Mocan and Erdal Tekin. All rights reserved. Short sections of text, not to exceed two paragraphs, may be quoted without explicit permission provided that full credit, including $(\mathrm{C}$ notice, is given to the source.
\end{abstract}


Nonprofit Sector and Part-Time Work: An Analysis of Employer-Employee

Matched Data of Child Care Workers

H. Naci Mocan and Erdal Tekin

NBER Working Paper No. 7977

October 2000

JEL No. J2, J3, J5, L3

\begin{abstract}
This paper uses a rich employer-employee matched data set to investigate the existence and the extent of nonprofit and part-time wage and compensation differentials in child care. The empirical strategy adjusts for workers' self-selection into the for-profit or nonprofit sectors, into full-time or part-time work, as well as unobserved worker heterogeneity using a discrete factor model. We find differences between the regimes (full-time for-profit, full-time nonprofit, part-time for-profit, part-time nonprofit) in the way in which human capital of the workers are rewarded. There is substantial variation in wages as a function of employee characteristics, and there is variation in wages within sectors. The results indicate that part-time jobs are "good" jobs in center-based child care. Furthermore, despite the evidence supporting the labor donation hypothesis, our results indicate the existence of nonprofit wage and compensation premiums, which support the property rights hypothesis.
\end{abstract}

\author{
H. Naci Mocan \\ Department of Economics \\ University of Colorado at Denver \\ Campus Box 181, PO Box 173364 \\ Denver, Co 80217-3364 \\ and NBER \\ nmocan@carbon.cudenver.edu
}

Erdal Tekin

Department of Economics

University of North Carolina at Chapel Hill

CB\# 3305, Gardner Hall

Chapel Hill, NC 27599-3305

etekin@email.unc.edu 
Nonprofit Sector and Part-Time Work: An Analysis of Employer-Employee Matched Data of Child Care Workers

\section{$\underline{\text { I. Introduction }}$}

The nonprofit sector constitutes a significant, and expanding segment of the U.S. economy. The number of private nonprofit organizations increased by almost 19 percent between 1989 and 1997, from 1,262,000 to 1,498,000 (Urban Institute 2000). The number of national nonprofit associations increased by 56 percent between 1980 and 1997, reaching almost 23,000 in 1997 (Statistical Abstract of the U.S. 2000). Employment in the nonprofit sector increased from 7.1 million full-time equivalent (FTE) paid workers in 1990 to 9.6 million FTE workers in 1995; and in 1995 nonprofit employment accounted for 8.8 percent of the GDP in the U.S. (Salamon et al. 1999). There are theoretical reasons to believe that economic behavior of nonprofit enterprises may be different from their for-profit counterparts (Lakdawalla and Philipson 1998, Rose-Ackerman 1986, Hansmann 1980). One such difference pertains to wage-setting behavior between nonprofit and for-profit firms. Nonprofit enterprises are expected to create rents for their workers, which would translate into wage mark-ups. Alternatively, if nonprofit workers differ from for-profit workers in their altruism, this may translate into a nonprofit "labor donation" and lower nonprofit wages. The empirical evidence on nonprofit wage differentials is ambiguous. As explained in Section II below, the literature is far from having reached a consensus on the issue.

Around 17 percent of all workers, and around one-quarter of all female workers work part-time (Bureau of Labor Statistics 2000). The fact that average wages of part-time workers are less than those of full-time workers with similar characteristics raises the question of whether part-time jobs are "bad" jobs (Blank 1990). ${ }^{1} \quad$ The substantial size of part-time employment makes this an important, and as yet unresolved, question.

Using an extraordinarily detailed employer-employee matched data set, this paper addresses two questions: Are wages and compensation of workers who work in the nonprofit sector lower than their counterparts in the for-profit sector; and are part-time jobs bad jobs?

\footnotetext{
${ }^{1}$ An investigation of whether certain jobs are bad jobs requires data on worker compensation as well as controls for job characteristics, which is not always possible because of the paucity of data. This
} 
We find that both answers are "no" for child care workers. Although we find evidence of labor-donation for nonprofit workers, we document substantial nonprofit premiums in wages and compensation. Similarly, we find that part-time jobs are "good" jobs. These results are not likely due to some idiosyncratic characteristic of the child care industry. As we demonstrate in the paper, the raw full-time and nonprofit differentials observed in our data show similar patterns when compared to a number of industries of the 1990 census data.

Section II gives the background, and puts the contribution of this paper into perspective. Section III presents the model and the data. Section IV describes the results, section V presents the sensitivity analysis, and section VI is the conclusion.

\section{$\underline{\text { II. Background }}$}

As summarized by Preston (1988), the theory of property rights predicts that nonprofit institutions may generate rents for their workers. This is partly because there is no owner to which the nonprofit manager is held accountable, which lessens the incentive for managers of nonprofit organizations to operate efficiently. As a result, there is reason to expect that nonprofit enterprises pay higher wages to comparable workers than their for-profit counterparts. On the other hand, it can be argued that nonprofit workers may have preferences that are different from for-profit workers. More precisely, some workers may be willing to work at nonprofit institutions at a lower wage and/or compensation in comparison to wages and compensation they could have obtained elsewhere. This labor donation could take place if nonprofit workers care about the social value of the good or service they produce more than for-profit workers (Preston 1989)

However, the empirical evidence on the nonprofit wage differential is ambiguous. Most of this ambiguity seems to stem from inadequate data sets employed to address the question. The investigation of nonprofit wage differentials takes two general forms. The first one is the analysis of firm-level data, such as in Preston (1988), who found that in the competitive segment of the day care industry, there is no significant difference in firm-level salaries between nonprofit and for-profit firms, whereas there is a 5 to 10 percent nonprofit differential in the government subsidized segment of the industry. Mocan and Viola (1997) investigated the determinants of wages and compensation in 398 child care centers. They 
found a positive nonprofit premium, which became statistically insignificant once sector breakdowns (e.g. religious center, publicly funded center) are controlled for.

A more refined investigation is done with micro data, where the determinants of worker wages are analyzed as a function of, among other factors, nonprofit status. Some analysts estimated wage regressions by including a dummy variable to indicate sector affiliation of the worker (e.g. Shackett and Trapani 1987, Borjas, Frech III and Ginsburg 1983) The findings of these studies may not be reliable because of the potential endogeneity of the sector dummy. As argued above, it is conceivable that workers who choose to work in the nonprofit sector may be systematically different from workers who work in the for-profit sector. If unobservable worker characteristics which influence sector choice also impact workers' wages one would obtain biased estimates of the sector impact. For example, Weisbrod (1983) estimated separate earnings functions for lawyers employed in public sector firms and those employed in private firms. He reported that public sector lawyers received lower wages than private sector lawyers. Using the same data set and by controlling for self-selection into sectors Goddeeris (1988) found no evidence that public sector lawyers accepted earning sacrifices, underlining the importance of selection bias. There are only a few papers that addressed selfselection of workers into sectors. Holtmann and Idson (1993) and Preston (1989) used the two-stage approach developed by Lee (1978) and Heckman (1979). Ruhm and Borkoski (2000) exploited the panel component of the Current Population Survey Outgoing Rotation Groups to control for self-selection.

For the most part, recent research on part-time wage differentials has paid attention to non-random selection into part-time work (Hotchkiss 1991, Blank 1990, Simpson 1986). However, most of the work in this literature faced challenges pertaining to measurement error in key variables (such as wages and hours), and a failure to control for non-wage benefits and other job attributes. As explained by Montgomery and Cosgrove (1995), the data sets employed in these studies did not allow for detailed controls for firm effects, or even occupation effects. While most papers reported a negative part-time wage differential (Montgomery and Cosgrove 1995, Simpson 1986), Blank (1990) found a wage differential in favor of part-time workers.

This paper brings together these two strands of literature: the wage setting practices of nonprofit enterprises, and the investigation of relative wages of part-time workers in 
comparison to their full-time counterparts. The employer-employee matched data set used in the analysis not only includes very detailed characteristics of workers and firms, it also allows for measurement of variables with more precision than before. For example, most studies that used national data sets had to impute worker wages using annual wage or salary income and annual hours (Leete forthcoming, Main and Reilly 1992, Blank 1990). They were also forced to impute certain human capital measures of the workers (e.g. experience). Similarly, data obtained from workers are likely to contain substantial error regarding the nonprofit status of the establishment they are working for (Leete forthcoming, Ruhm and Borkoski 2000). By contrast, in our data set the information pertaining to the firm is obtained from child care centers' directors and from their financial statements. All worker information such as workers' experience in the field, experience outside the field, and tenure on the job, is obtained by surveying the workers directly.

The richness of the data set allows for tests of several interesting hypotheses, which were not directly tested before. For example, a question had been included in the survey given to workers to test the labor donation hypothesis. Workers were asked about the main reason for their choice of the child care industry. Among the alternatives given to them was: "I think this is an important job someone needs to do." We test whether nonprofit workers who chose this alternative as their main reason of employment face a wage or compensation penalty as predicted by the labor donation hypothesis.

Using the information on the types and dollar amount of nonwage benefits offered by the centers, and the information on the type of staff which receives these benefits, we are able to calculate hourly compensation, and conduct the analysis for compensation as well. We allow

for endogenous selection of sector (nonprofit vs. for-profit) as well as hours (part-time versus full-time). Controlling for unobserved individual heterogeneity, the model is estimated for both wages and compensation using full-information maximum-likelihood.

\section{Empirical Implementation}

The model includes two selection equations and four sectoral wage equations. One selection equation allocates child care workers to the for-profit or the nonprofit sector, while the other one allocates them to either full-time or part-time work. The cross-classification of 
these two selection rules partitions workers into four mutually exclusive categories. ${ }^{2}$ The selection between the for-profit and nonprofit sectors and between full-time and part-time work can be summarized by the following equations.

(1) $\quad \mathrm{PR}_{\mathrm{i}}^{*}=\mathbf{X}_{\mathrm{i}} \boldsymbol{\beta}+\epsilon_{\mathrm{i}}^{\mathrm{p}}$

(2) $\quad \mathrm{FT}^{*}{ }_{\mathrm{i}}=\mathbf{Y}_{\mathrm{i}} \boldsymbol{\gamma}+\boldsymbol{\epsilon}_{\mathrm{i}}^{\mathrm{ft}}$

where $\mathrm{PR}^{*}$ stands for unobserved sentiment that determines the attachment to the forprofit sector, and $\mathrm{FT}^{*}$ is the unobserved tendency to choose full-time work, such that $\mathrm{PR}=1$ (the worker chooses the for-profit sector) if $\mathrm{PR}^{*}>0$, and $\mathrm{PR}=0$ otherwise. Similarly, if $\mathrm{FT}^{*}>0$ then the worker chooses full-time work and the dichotomous variable FT takes the value of 1 , and $\mathrm{FT}=0$ otherwise. The vectors $\mathbf{X}$ and $\mathbf{Y}$ are variables that determine the propensity to work in the for-profit sector, and to work full-time, respectively.

We specify linear sectoral wage equations as follows.

$$
\begin{gathered}
\mathrm{W}_{\mathrm{i}}^{\mathrm{ft}-\mathrm{np}}=\mathbf{Z}_{\mathrm{i}} \boldsymbol{\delta}+\epsilon_{\mathrm{i}}^{\mathrm{ft}}{ }^{\mathrm{fnp}} \\
\mathrm{W}_{\mathrm{i}}^{\mathrm{pt}-\mathrm{np}}=\mathbf{Z}_{\mathrm{i}} \zeta+\epsilon_{\mathrm{i}}^{\mathrm{pt}}{ }^{\mathrm{t}-\mathrm{np}} \\
\mathrm{W}_{\mathrm{i}}^{\mathrm{ft}-\mathrm{pr}}=\mathbf{K}_{\mathrm{i}} \pi+\epsilon_{\mathrm{i}}^{\mathrm{ft}-\mathrm{pr}} \\
\mathrm{W}_{\mathrm{i}}^{\mathrm{pt}-\mathrm{pr}}=\mathbf{K}_{\mathrm{i}} \lambda+\epsilon_{\mathrm{i}}^{\mathrm{pt}-\mathrm{pr}},
\end{gathered}
$$

where the superscript $f t$ stands for full-time, $p t$ stands for part-time, $n p$ is nonprofit and $p r$ represents for-profit. $\mathrm{W}_{\mathrm{i}}$ stands for the wage rate of the $i$ th worker. The vector $\mathbf{Z}$ contains variables determining the wages in the nonprofit sector, and $\mathbf{K}$ is the vector of variables that determines wages in the for-profit sector. Some elements of $\mathbf{Z}$ are naturally missing from $\mathbf{K}$, and vice versa, which facilitates identification. For example, there are no unionized or religious centers among for-profits. Similarly, no for-profit center is publicly owned or regulated. On the other hand, there are no nonprofit centers which are part of a national chain or which provide 24-hour care. Thus, the variables representing the union status, the religious affiliation, and public ownership of the centers are included in $\mathbf{Z}$, but are missing from $\mathbf{K}$. Along the same lines, the variables that represent whether or not the center is part of a national chain and whether the center provides 24 -hour care are in $\mathbf{K}$, but are missing from $\mathbf{Z}$. The variables that represent family background such as household income, marital status of the

\footnotetext{
${ }^{2}$ Another potential selection is into the labor force. We do not address it here because of the lack of data on nonworkers.
} 
worker, and the number of children are included in the selection equations, but they are omitted from the wage equations. To the extent that the latent variables that measure the propensity to work full-time and the propensity to work in the for-profit sector are influenced by potential wages in these sectors, the variables that are included in $\mathbf{Z}$ and $\mathbf{K}$ should be included in $\mathbf{X}$ and $\mathbf{Y}$. However, variables that are affiliated exclusively with one sector (such as the union status) are not included in the selection equations.

It is plausible to think that the error term of the sector selection equation may be correlated with the error term of the full-time selection equation. That is, workers' unobserved preferences for sector choice may impact their choice of full-time versus part-time work. These disturbances may also be correlated with the disturbances of the wage equations: unobserved worker characteristics which influence sector and full-time choice decisions may impact wages.

To account for this potential correlation in the errors of the equations, we model the error structure as

$$
\begin{aligned}
& \epsilon_{\mathrm{i}}^{\mathrm{pr}}=\mathrm{u}_{1}+\sum_{\mathrm{j}=1}^{\mathrm{m}} \rho_{\mathrm{j}}^{\mathrm{np}} v_{\mathrm{j}} \\
& \epsilon_{\mathrm{i}}^{\mathrm{ft}}=\mathrm{u}_{2}+\sum_{\mathrm{j}=1}^{\mathrm{m}} \rho_{\mathrm{j}}^{\mathrm{ft}} v_{\mathrm{j}} \\
& \epsilon_{\mathrm{i}}^{\mathrm{ft}-\mathrm{pp}}=\mathrm{u}_{3}+\sum_{\mathrm{j}=1}^{\mathrm{m}} \rho^{\mathrm{ft}-\mathrm{pp}} v_{\mathrm{j}} \\
& \epsilon_{\mathrm{i}}^{\mathrm{pt}-\mathrm{pp}}=\mathrm{u}_{4}+\sum_{\mathrm{j}=1}^{\mathrm{m}} \rho_{\mathrm{j}}^{\mathrm{pt}-\mathrm{np}} v_{\mathrm{j}} \\
& \epsilon_{\mathrm{i}}^{\mathrm{ft}-\mathrm{pr}}=\mathrm{u}_{5}+\sum_{\mathrm{j}=1}^{\mathrm{m}} \rho_{\mathrm{j}}^{\mathrm{ft}-\mathrm{pr}} v_{\mathrm{j}} \\
& \epsilon_{\mathrm{i}}^{\mathrm{pt}-\mathrm{pr}}=\mathrm{u}_{6}+\sum_{\mathrm{j}=1}^{\mathrm{m}} \rho_{\mathrm{j}}^{\mathrm{pt}-\mathrm{pr}} v_{\mathrm{j}}
\end{aligned}
$$

where $u_{1}, \ldots, u_{6}$ are mutually independent disturbances with mean zero, and $v_{j}$ symbolizes the common factors that impacts error terms $\epsilon$. The factor loadings, $\rho_{\mathrm{j}}$, allow for the impact of the common factors to vary cross equations. u's and v's are independent of the explanatory variables. The factors ( $v$ 's) are unobserved variables that generate worker heterogeneity. We allow for two factors to account for the correlations among equations. For example, one factor 
might represent unobserved motivation, and the other one may represent tastes for work.

In principle, one can estimate this system by imposing a parametric joint distribution for the two sources unobserved of heterogeneity and integrating out over its distribution. The drawback to this approach is that it requires computing multi-dimensional integrals, which is not feasible with traditional methods. Furthermore, it requires strong assumptions about the exact distribution of the heterogeneity. In related contexts, it has been shown that the results can be sensitive to departures from normality (Goldberger 1983, Arabmazar and Schmidt 1982).

In this paper we use the discrete factor method (DFM) which, unlike standard selection corrections, estimates a semiparametric distribution to approximate the distribution between the error term of the selection and wage equations. In this approach the distribution of the $v$ 's is approximated with a step function and integrated out through a weighted sum of probabilities (Heckman and Singer 1984, Mroz 1999). Following Mroz (1999), we assume that $v$ is governed by a discrete distribution

$$
\operatorname{Prob}\left(v=\mu_{\mathrm{k}}\right)=\psi_{\mathrm{k}} ; \mathrm{k}=1, \ldots, \mathrm{K} ; \psi_{\mathrm{k}} \geq 0, \quad \sum_{\mathrm{k}} \psi_{\mathrm{k}}=1,
$$

where $\mu_{\mathrm{k}}$ are the points of support of the distribution, and $\psi_{\mathrm{k}}$ are the probability weights. The $\mu_{\mathrm{k}}$ 's, $\psi_{\mathrm{k}}$ 's, $\rho$ 's are parameters to be estimated. $\mathrm{K}$ is specified a priori, and the six equations are estimated jointly with full-information maximum likelihood. ${ }^{3}$ Mroz (1999) demonstrates that when the true correlation of the error terms is normal, DFM performs well in comparison to estimators which assume normality; and DFM performs better than normality-based estimators when the underlying distribution is non-normal. (See Blau and Hagy (1998), Hu (1999), Blau and Mocan (1999) and Mocan, Tekin and Zax (2000) for applications of the discrete factor model).

\section{The Data}

We use a recent data set obtained from child care centers in California, Colorado, Connecticut and North Carolina. ${ }^{4}$ The data are based upon a stratified random sample of 398

3 The likelihood function is presented in the Appendix.

4 The data were compiled with the collaboration of economists, psychologists and child development experts from University of Colorado at Denver, Yale University, University of North Carolina at 
day care centers (approximately 100 centers from each participating state), with equal representation of for-profit and nonprofit programs, providing full-time year-round care. They were obtained by actual visits to the centers during the spring of 1993. Data collectors gathered in-depth financial information on center costs and revenues, various non-wage benefits offered to teachers, aides and part-time staff, ownership and union status, and a host of other center characteristics through on-site interviews and reviews of center records with center administrators or owners. In each of the 398 centers in the data set, two classrooms were randomly selected: one from the older children (30 months and older) and one from the younger groups. Teaching staff in these classrooms were asked to complete a survey regarding their human capital characteristics, their pre-tax hourly wages, weekly hours of work, family characteristics and attitudes towards work in the child care industry. As a result, the extraordinary detail of the data allows for control of the job environment, as well as worker and firm characteristics with precision.

Table 1 presents average hourly wages and compensation by state, nonprofit status and full-time status (workers who work 35 or more hours per week). ${ }^{5}$ Cells within a box indicate statistically significant differences (at the five percent level or less) between nonprofit and forprofit sectors in the corresponding column. For example, in Colorado the average wage of full-time workers in the nonprofit sector is $\$ 6.38$; the average wage in the for-profit sector is $\$ 5.68$, and the difference is statistically significant as indicated by the box around these means. Entries with a star signify statistically significant differences between full-time and part-time means in the corresponding row. For example, in California, in the for-profit sector, the mean wage for full-time workers is $\$ 8.12$ while the mean wage of part-time workers is $\$ 7.19$; and the difference is statistically significant.

Table 1 illustrates raw nonprofit wage and compensation differentials. In Connecticut and North Carolina both wages and compensation are higher in nonprofit centers than forprofit centers for both full-time and part-time workers. The same is true for full-time workers in Colorado. Part-time workers' compensation is higher in nonprofit centers in California. Table 1 also displays raw wage and compensation differences in favor of full-timers. With the exception of wages in Connecticut nonprofit centers, average wages and compensation are

Chapel Hill and UCLA. The details of the data and data collection can be found in Mocan (1997). 
higher for full-timers, and the differences are especially prevalent in California and North Carolina.

Raw full-time and nonprofit differentials are presented in a more compact fashion in Table 2. We ran linear regressions of the logarithm of wages and compensation on state dummies and a full-time dummy, separately for nonprofit and for-profit centers to obtain the information displayed in the top half of Table 2. The logarithm of wages and compensation are run on state dummies and a for-profit dummy separately for full-time and part-time workers to obtain the information displayed in the bottom half of the table. The values in parentheses are percentage differences. According to Table 2, controlling for state differences, full-time wages are not different from part-time wages in nonprofit centers, but full-time compensation is greater than part-time compensation. In for-profit centers both wages and compensation are greater for full-time workers. The bottom half of the Table demonstrates that there exist nonprofit mark-ups in both wages and compensation.

Table 3 presents the descriptive characteristics of the workers. Sixty-five percent work full-time. In Colorado, 80 percent of for-profit workers are full-time, while the ratio is 69 percent for nonprofit workers. In other states there is no statistically significant difference between sectors regarding the proportion of workers who work full-time. Even though 97 percent of the workers are female, as will be seen in the results section, gender turns out to be a significant determinant of wages for part-time workers. Experience is the number of years worked in the field of early education and child care. The workers are instructed that work means 10 or more hours a week. It includes paid and non-paid experience, and includes time at the particular center they are currently working.

The highest degree is a high school diploma for 19 percent of the workers, and another 19 percent have college degrees. Fourteen percent have community college degrees. Assistant teacher is a dichotomous variable which takes the value of 1 is the worker is an assistant teacher, and zero is he/she is a teacher in the classroom. Own kids is the number of children (birth, adopted, foster or step children) living with the worker full or part-time. Own kids at center is a dummy variable to indicate whether or not the worker's own children are attending the center.

Organization is equal to one if the worker belongs to any professional organization,

\footnotetext{
5 The measurement of compensation is described in the appendix.
} 
such as the National Association for Education of Young Children. The workers were asked about the main reason for their choice of work in the field of early education and child care. The alternatives given were: it was the highest paying job at the time; it is a desirable job (pleasant job environment); low cost of working; flexible working hours; and this is an important job that someone needs to do. If the worker chose this last alternative, then the dummy variable Important job takes the value of one; and zero otherwise. This variable is a direct indicator of the intrinsic value to the individual of working in the child care sector. As such, it allows for a direct test of the "labor donation" hypothesis; that is, all else the same, individuals with this attitude are expected to command lower wages, especially in the nonprofit sector.

Single is equal to one if the worker is single, living alone with a roommate or parent(s) and zero otherwise. Married is another dummy variable to indicate whether the person is married, or living with a significant other. The left-out category is whether the person is divorced or separated, a widow or widower. Household income is measured by six dichotomous variables. Forty-two percent of the workers have household incomes less than $\$ 20,000$.

Table 3A presents worker descriptive statistics by type of worker. A star indicates that the means are statistically different between for-profit and nonprofit, or between full-time and part-time workers at the five-percent level or better. For example, nonprofit workers are older than for-profit workers (35 years of age vs. 31 years), and they also have more tenure (45 months vs. 30 months). Similarly, nonprofit workers have almost one more year of experience, are more likely to be a member of a professional organization, and are more likely to be black or Hispanic. Nonprofit workers have an average of 0.24 more children. On the other hand, 20 percent of for-profit workers have children at the center, while the rate is 11 percent for nonprofit workers. Twenty-three percent of for-profit workers are have a college degree, while the rate is 15 percent for nonprofit workers. There is no difference between forprofit and nonprofit workers regarding their household income.

Part-time workers are older than full-time workers, and they have more job tenure. A higher proportion of full-time workers is single, and a smaller proportion is married. Fourteen percent of full-time workers are black, while the rate is 10 percent for part-time workers. Full-time workers are more likely to have come from poorer households. 
Table 4 displays the descriptive statistics of center characteristics. For-profit takes the value of 1 if the center is for-profit, and 0 if it is nonprofit. National chain is also a dichotomous variable, indicating whether the center is part of a for-profit national chain. Onsite is set to 1 if the center is a worksite child care center, and zero otherwise. Publicly Regulated is 1 if the center receives public money, either from the state or federal government, tied to higher standards (above and beyond normal licensing regulations), and 0 otherwise. This group includes Head Start programs, centers where 20 percent or more of their enrollment constitute special needs children, special preschool programs sponsored by the State or Federal Department of Education, and other special programs in Connecticut and California.

Publicly owned is set to 1 for centers that are owned and operated by public agencies. Examples include public colleges, hospitals, and city departments of family services. Publicly supported is another dichotomous variable which takes the value of 1 if the center is not publicly owned or operated, but receives more than 50 percent of its revenue from public grants, public fees and USDA reimbursement. Religious is 1 if the center has a religious affiliation (e.g. church-based centers), and zero otherwise. Union is 1, if teachers and/or aides are unionized. There are 18 unionized centers in the sample, and all are nonprofit centers. Of these, 14 are publicly owned centers (Publicly owned), 2 are publicly supported centers (Publicly supported) and 2 are religious centers.

Percent subsidized represents the proportion of children that are subsidized by a government or other agency, such as the State or County Department of Social or Human Services, United Way, etc. Table 4 also displays information about various programs offered by centers, such as evening care, sick care, and before-and-school care.

Following an extensive literature that investigates the impact of firm size on earnings (Troske 1999, Main and Reilly 1993, Brown and Medoff 1989, Evans and Leighton 1989), we add the size of the child care center, measured by full-time equivalent children (FTE Children) in the wage and compensation equations. Local unemployment can depress wages through various non-competitive mechanisms (Blanchflower and Oswald 1994, Chapter 3). Alternatively, there can be a positive relationship between wages and unemployment, because firms can provide compensating wage differentials to workers in the spirit of the Harris and 
Todero (1970) and Hall (1970) models. To investigate this effect, we include the unemployment rate in the models. Unemployment is the unemployment rate in the city where the center is located. The zip codes of the centers are used to determine the city in which the center is located. The unemployment rates for the corresponding cities are obtained from the U.S. Bureau of Labor Statistics, Local Area Unemployment Division. For the cities where BLS figures were unavailable, the unemployment rates are imputed as the average unemployment rates of the neighboring cities within a 20 mile radius.

\section{Results}

Equations (1)-(6) are estimated jointly with full-information maximum likelihood under the error structure displayed by (7)-(12). The results are based on five points of support ( $\mathrm{K}=5$ in Equation 13). Table 5 displays the estimated coefficients of the for-profit selection and fulltime selection equations. Education has a positive impact on the propensity to work full-time. Having a graduate degree makes it more likely to choose the for-profit sector. Single and married individuals are less likely to choose work in the for-profit sector in comparison to divorced and widowed ones, but singles are more likely to work full-time. Hispanics and blacks are less likely to choose the for-profit sector, and are more likely to work full-time. Ruhm and Borkoski (2000) find that economy-wide low average nonprofit wages reflect the concentration of nonprofit jobs in low-paying industries. They indicate that this could be because of the selection of disadvantaged groups or low quality workers into these industries. Here we find that in a narrowly defined industry, blacks and Hispanics self-select into the nonprofit sector.

Being a member of a professional child care organization has a negative impact on the probability to work in the for-profit sector. Workers from households with an annual household income less than $\$ 50,000$ are more likely to work full-time in comparison to workers from households with incomes greater than $\$ 50,000$. An increase in the number of children of the worker has a negative impact on the propensity to choose the for-profit sector as well as to work full-time. Local unemployment has no impact on the choice of sector, but it has a negative impact on the probability of working full-time.

Table 6 displays the estimated coefficients of the four wage equations. The dependent variables are the logarithm of wages. The coefficients of Tenure and Experience are positive 
and significantly different from zero in all wage equations. One additional year of tenure increases wages by 2.4 percent for part-time workers in both sectors (tenure is measured in months). For full-time workers the return to tenure is 1.2 percent in the for-profit sector, and 0.5 percent in the nonprofit sector. The return to experience is similar between full-time and part-time workers within sector, but the returns are higher in the nonprofit sector. Experience outside child care is rewarded most heavily for part-time nonprofit workers.

Education is rewarded more in the nonprofit sector. In the nonprofit sector workers with at least a high school diploma earn wages that are higher than comparable workers with no high school degree. For for-profit workers, education has a wage premium (in comparison to no high school diploma) if the worker has a community college education or higher. Lack of special training in child care is associated with lower wages in both sectors for both types of workers, while the penalty is higher in the nonprofit sector.

Table 7 presents the results of a series of hypothesis tests pertaining to the equality of the coefficients of human capital variables. ${ }^{6}$ The sign of the calculated t-statistic reveals the direction of the difference between the coefficients under test. A positive t-statistic indicates that the first coefficient under the hypothesis is greater than the second one in magnitude. ${ }^{7}$ For example, the first test reported in the table pertains to the hypothesis that the coefficients of tenure are equal to each other in for-profit and nonprofit sectors for full-time workers. The calculated t-value is 3.627, which indicates that the coefficients are different from each other, and the for-profit coefficient is larger.

As Table 7 demonstrates there are differences between for-profit and nonprofit centers regarding the manner in which human capital characteristics affect wages. For full-time workers, the return to tenure is higher in for-profit centers, but the return to experience, return to a college degree and to a graduate degree are higher in nonprofit centers. Section II shows that experience in the child care sector, other experience, and a graduate degree are rewarded more in the nonprofit sector for part-time workers. Similarly, the lack of special training in child care lowers wages of part-time workers more in the nonprofit sector. On the other hand,

\footnotetext{
${ }^{6}$ The hypothesis tests utilize the information reported in Table 6 along with the variance-covariance matrix of the estimated coefficients.

7 The exception is the test pertaining to the coefficients of Special Training. Because these coefficients are always negative, a positive $t$-statistic indicates that the first coefficient is smaller than the second one in absolute value.
} 
a community college degree has a higher return in the for-profit sector. With the exception of Other Experience in Section III and Experience in Section IV, all significant t-values have negative signs in Sections III and IV. This demonstrates that part-time coefficients are larger in magnitude than full-time coefficients in both for-profit (Section III) and nonprofit centers (Section IV), and indicates that the return to education is higher for part-time workers in both sectors.

Coming back to Table 6, we see that female part-time workers earn 11 percent and four percent less, respectively, in the for-profit and nonprofit sectors in comparison to their male counterparts. Race is also a determinant of wages, where blacks and Hispanics receive positive premiums, and white and Asian part-time workers in the nonprofit sector command lower wages.

The labor donation hypothesis states that workers in the nonprofit sector are more concerned about the nature of the service they are providing, and therefore they would be willing to work for a wage which is less than they could have earned elsewhere. The dichotomous variable Important job takes the value of one if the worker indicated that the primary reason for his/her choice of the child care sector was that it was "an important job someone needed to do." Thus, to the extent that this variable is capturing the attitudes toward labor donation, the coefficient of Important job should be negative in the nonprofit wage equation. Table 6 shows that the coefficient of important job is negative for both full-time and part-time workers in the nonprofit sector, with a bigger magnitude for full-time workers. It is positive in the for-profit sector, although statistically significant only for full-time for-profit workers. This is an interesting result, which supports the labor donation hypothesis for nonprofit workers. It also suggests that this particular attitude may be correlated with productivity, which is rewarded in the for-profit sector.

Being a member of a professional organization (Organization) has a positive impact on wages, although it is not significant for part-time for-profit workers. The positive relationship between membership to a professional child care organization and wages may emerge because member workers may be rewarded for providing a signal of dedication to early child care education. Alternatively, membership may be correlated with effort and productivity.

Job title has an impact on wages of all types of workers. If the worker is an assistant teacher his/her wage is lower in comparison to teachers in the regime. The discrepancy is 
especially prevalent for part-time nonprofit assistant teachers, where their wages are 15 percent lower than comparable teachers in the same sector. All else the same, if the worker is working in an infant-toddler room, his/her wage is lower in comparison to workers who are working in preschool or kindergarten/school age classrooms. This may be because serving infant-toddlers is perceived as an easier job than serving older children.

Center characteristics have significant impacts on wages. For example, wages in onsite centers are substantially higher for both full-time and part-time workers in both sectors. For-profit centers, which are part of a national chain, offer wages to full-timers and part-timers that are six percent and 12 percent lower, respectively, in comparison to non-chain for-profit centers. If the center is publicly supported, then the wages of full-timers are 12 percent lower in comparison to other full-time workers in other nonprofit centers. On the other hand, publicly supported centers offer a six percent wage premium to part-time nonprofit workers. Publicly owned centers in the nonprofit sector generate wage premiums to their workers. Publicly regulated nonprofit centers' wages are higher for full-time workers, but lower for part-time workers. Wages are three-to-four percent lower in religious centers.

There is a substantial union wage premium in nonprofit centers. Unionized nonprofit centers provide a 22 percent wage premium to both full-time and part-time workers. The union variable in the analysis indicates whether or not the center is unionized. The impact of this union variable on part-time wages has two possible explanations. The first explanation is that part-time workers are also covered by the union. Alternatively, part-time workers are not covered by the union, but the union impact on part-time wages reflects a spillover effect. We attempted to contact the unionized centers in the data set to ask whether part-time workers were also covered by the union in 1993 . We could not reach four out of the 12 centers either because they were not in operation any longer, or their phone numbers have changed. Four of the remaining eight centers indicated that part-time workers were also covered by the union. One center indicated that part-timers were not covered by the union, and three centers could not answer the question. So, the channel through which the union impact on part-time wages operates remains unclear.

Local unemployment has a negative impact on part-time nonprofit workers' wages. Larger for-profit centers pay a wage premium to both full-time and part-time workers which is consistent with the literature on size differentials (see Troske 1999). On the other hand, there 
is a negative relationship between center size and wages in the nonprofit sector. Older centers pay lower wages to full-time workers, but higher wages to part-timers. Economic background of the parents and children at the center is measured by the proportion of children who are subsidized. An increase in the proportion of subsidized children is negatively related to parttime wages, as well as full-time nonprofit wages.

Other center characteristics also have significant impacts on wages. For example, partweek programs provide lower wages for part-time workers. Nonprofit centers with part-day extended care programs offer higher wages. Head Start programs offer wages to full-time workers that are 25 percent lower than non-Head Start nonprofit centers. Head Start wages are seven percent lower for part-time workers.

If nonprofit centers accept children even when they are sick (Sick care), they offer higher wages to part-time workers. If for-profit centers offer 24-hour care, they offer higher wages to their part-time workers. To the extent that serving sick children is less appealing and more difficult than serving healthy children, from workers' point of view, this result may be a reflection of a compensating wage differential. The same can be said for 24-hour case. Along the same lines, to the extent that having one's own child at the same center is a desirable job attribute, this is expected to lower wages for workers whose children are attending the same center. However, in three out of four regimes, the relationship is not significantly different from zero, and it is positive for part-time nonprofit workers. In Tables 8 and 9 we present the estimated coefficients of the same model with hourly compensation. Table 8 displays the estimated selection equations, while Table 9 presents the four compensation equations. The results are similar to the ones obtained from wage regressions

The estimated equations enable us to investigate what a randomly chosen individual's wage and compensation would be under the four possible regimes (full-time, for-profit; fulltime, nonprofit; part-time, for-profit; and part-time, nonprofit). Using the estimated parameters of the system and the estimated heterogeneity coefficients, we simulated the potential wages and compensation for all workers in the sample under the four possible regimes. That is, we calculated selection-corrected and heterogeneity-adjusted wages and compensation that each worker would earn if assigned to a particular regime. The prediction errors of wages and compensation are also calculated for each worker under each regime. This allows for the calculation of the standard errors of the means. Calculation of the 95-percent 
confidence intervals around the means indicate that we can reject the hypotheses of the equality of wages and compensation with the exception of full-time and part-time wages in the for-profit sector as their confidence intervals overlap. ${ }^{8}$ Table 10 presents the direction and the magnitudes of the mark-ups. After controlling for selection effects and unobserved worker heterogeneity, full-time wages are 12.5 percent lower than part-time wages in nonprofit centers, and they are equal to part-time wages in for-profit centers. This is not a common result in the literature, but it is not without precedent. Blank (1990) also found that selectionadjusted wages of part-time workers were higher than comparable full-time workers. She was unable to do her analysis using compensation because of lack of data. In nonprofit centers, the compensation mark-up is also in favor of part-timers, and larger than wage mark-up in magnitude (24.9 percent). This indicates that not only part-time workers' wages are higher than full-time workers' wages in nonprofit centers, but part-time workers receive more benefits per hour worked than full-time workers in the nonprofit sector.

Although part-time workers' wages are equivalent to full-time workers' wages in forprofit centers, the average compensation of part-time workers is 23 percent higher than that of full-time workers in for-profit centers, indicating that, similar to the pattern in nonprofit centers, for-profit centers provide more benefits to part-time workers. These results are in sharp contrast to the raw data revealed in Table 2.

The bottom part of Table 10 demonstrates that full-time workers' wages are 5.8 percent higher in the nonprofit sector in comparison to what they would have earned in the for-profit sector. The nonprofit full-time mark-up is 7.8 percent in compensation. Part-time workers' wages and compensation are higher in the nonprofit sector in comparison to the for-profit sector. However, the mark-up is smaller in compensation, suggesting that for-profit centers provide better benefits than nonprofit centers in the case of part-time workers.

These results indicate that part-time jobs are good jobs in child care. The fact that the raw wage differences are in favor of full-time workers may imply that, as suggested by Blank (1990), part-time workers may have earned lower wages even when they worked full-time, due to additional unobserved worker or job attributes. The results also support the property rights hypothesis as we uncover significant nonprofit wage and compensation differentials.

8 The standard errors for wage equations in pr-ft, np-ft, pr-pt and np-pt are $0.0045,0.0054,0.0030$ and 0.0009 , respectively. They are $0.0024,0.0019,0.0013$ and 0.0017 for compensation equations. 
$\underline{\text { V. Sensitivity Analysis and Representativeness of the Data }}$

Our analysis included detailed worker and firm attributes. Examples are "Organization" and "Important Job" for workers, and "Percent Subsidized," "Center Age," "Part-week," "Extended Care," "Head Start," "Before and After School," "Summer Camp," "Evening Care," "Sick Care," and "24 Hour Care" for firms. To investigate the importance of controlling for these worker and firm characteristics, we omitted these variables from the system and re-estimated the models. Omission of these variables implies 44 restrictions on the unrestricted models reported in Tables 5-6 and 8-9. The calculated likelihood ratio was 614.46 for the wage model, and 652.6 for compensation, strongly rejecting the hypothesis that these worker and firm attributes are unimportant. Furthermore, with the omission of these variables both wage and compensation models provided different results regarding the mark-ups in comparison to the ones reported in Table 10. More specifically, the nonprofit wage mark-up for full-time workers became -5.1 percent (as opposed to the positive 5.8 percent reported in Table 10). Similarly, the nonprofit compensation differential for full-time workers (reported as 7.8 percent in Table 10) is estimated as -2.1 percent in the restricted model.

In addition to the omitted variables mentioned above, we further reduced the models by omitting the following firm characteristics: "On-site," "National Chain," "Publicly Supported," "Publicly Owned," "Publicly Regulated," and "Religious." In other words, we made our models similar to other papers in the literature which included information on nonprofit status of the firm, but did not have additional information about the details of the ownership. These additional omitted variables generate an additional 16 restrictions. We found that these additional restrictions hurt the models even further. The calculated likelihood ratio was 235.4 for the wage system (while the one-percent critical value is 32 for 16 degrees of freedom), and 48.4 for the compensation system. The nonprofit wage differential for fulltime workers was -4.7 percent, and the full-time mark-up in the for-profit sector was 6.2 percent. Once again, the results are different from the ones obtained from the original models. This exercise underscores the importance of detailed worker and firm characteristics, and highlights the incorrect inferences that can be made in their absence.

Can these results be attributable to some anomaly of the child care industry? To entertain this question, we used the Five-Percent Public Use Sample (PUMS) of the 1990 
census. We extracted all workers with positive wages and salary income who worked in hospitals, nursing and personal care facilities, elementary and secondary schools, colleges and universities, educational services, bus service and urban transit, and research, development and testing services. These industries have bigger nonprofit presence than others. To investigate the raw nonprofit and full-time wage differentials in these industries we ran regressions of the logarithm of wages on nonprofit and full-time dummies as well as state dummies. The results are reported in Table 11. The nonprofit wage premium is positive in all cases, although not significant in educational services. Raw full-time wage mark-up is zero in hospitals, and negative in nursing and personal care, but positive everywhere else. Thus, the descriptive information from the 1990 census shows that the raw nonprofit and full-time mark-ups of the child care industry are similar to those observed in many other industries with a significant nonprofit presence, indicating that our results are not likely to be driven by some idiosyncratic structure of the child care industry.

\section{Summary}

This paper uses a rich employer-employee matched data set to investigate the existence and the extent of nonprofit and part-time wage and compensation differentials. Utilizing data exclusively on child care workers we avoid potential contamination of results due to interindustry unobservables. The raw data reveal wage and compensation premiums in favor of nonprofit workers. They also reveal the existence of wage and compensation premiums in favor of full-time workers in for-profit centers, and compensation premium in favor of fulltime workers in the nonprofit sector. An analysis of the 1990 Census data shows that these raw differentials are similar to those found in many industries significant nonprofit sector presence.

The empirical strategy adjusts for workers' self-selection into the for-profit or nonprofit sectors, as well as into full-time or part-time work. We also control for unobserved worker heterogeneity using a discrete factor model. The wage and compensation equations are estimated jointly with the selection equations using full-information maximum likelihood.

We find differences between the regimes (full-time for-profit, full-time nonprofit, parttime for-profit, part-time nonprofit) in the way in which human capital of the workers are rewarded. For example, in both for-profit and nonprofit sectors, the return to education is 
higher for part-time workers. For full-time workers, the return to tenure is higher in for-profit centers. In nonprofit centers, the return to experience in child care for full-time workers is higher than that of part-time workers, and in for-profit centers the return to experience outside child care is higher for full-time workers.

There is substantial variation in wages as a function of employee characteristics, and there is variation in wages within sectors. For example, unionization increases wages and compensation 20-25 percent, and centers that are part of a national chain provide lower wages and compensation. Other examples are the job title of the worker and the age group of the children he/she is serving. Similarly, center characteristics such as the age and the size of the center, whether the center is publicly supported, publicly owned or regulated, whether it is a religious center impact wages and compensation. Along the same lines, various programs offered by the centers (e.g. sick care, evening care) have significant impacts.

We provide the first direct test of the labor donation hypothesis. A question is specifically included in the survey given to the workers to identify the primary reason for the worker's choice of employment in child care. Workers who chose the alternative "this is an important job someone needs to do," receive two to five percent lower wages in the nonprofit sector, which supports labor donation hypothesis.

After estimating the models, we calculate the wage and compensation that each worker in our sample would have received under each regime after controlling for non-random selection and unobserved worker heterogeneity. We find that potential wages of part-time workers are equivalent to those of full-time workers in the for-profit sector, and they are higher in the nonprofit sector. Part-time workers' compensation is higher than that of fulltimers in both sectors, and the compensation mark-up is larger than the wage mark-up. This suggests that part-time workers receive more benefits in both sectors. We find evidence of positive nonprofit wage differentials for both full-time and part-time workers. Compensation is also higher in the nonprofit sector for both types of workers.

The magnitudes of these differentials are substantial. For example, nonprofit wage differential is almost six percent for full-time workers and 20 percent for part-time workers. Nonprofit compensation differential is eight percent for full-time workers and 10 percent for part-time workers. Similarly, part-time workers earn wages that are 13 percent more than fulltime workers in nonprofit centers. Part-time compensation is 25 percent more than full-time 
compensation in nonprofit centers, and 23 percent more in for-profit centers.

These results underscore important points. First, it seems critical to control for the impact of worker self-selection into sector and into full-time work. Second, it is important to have detailed controls for both employer and employee characteristics as they have significant impacts.

The results indicate that part-time jobs are "good" jobs in center-based child care. Furthermore, despite the evidence supporting the labor donation hypothesis, our results indicate the existence of nonprofit wage and compensation premiums, which support the property rights hypothesis. 
Table 1

Average Wage and Compensation

\begin{tabular}{|c|c|c|c|c|c|}
\hline & & \multicolumn{2}{|c|}{ Wage } & \multicolumn{2}{|c|}{ Compensation } \\
\hline & & Full-Time & Part-Time & Full-Time & Part-Time \\
\hline \multirow[t]{2}{*}{ California } & Nonprofit & 8.24 & 7.71 & $10.00 *$ & $8.90 *$ \\
\hline & For-Profit & $8.12 *$ & $7.19 *$ & $9.38 *$ & $8.00 *$ \\
\hline \multirow[t]{2}{*}{ Colorado } & Nonprofit & 6.38 & 6.19 & 7.37 & 6.80 \\
\hline & For-Profit & 5.68 & 5.65 & 6.49 & 6.17 \\
\hline \multirow[t]{2}{*}{ Connecticut } & Nonprofit & $8.37 *$ & $9.39 *$ & 10.42 & 10.77 \\
\hline & For-Profit & 7.41 & 7.24 & 8.56 & 8.20 \\
\hline \multirow[t]{2}{*}{ North Carolina } & Nonprofit & 5.97 & 5.58 & $7.09 *$ & $5.70 *$ \\
\hline & For-Profit & $5.27 *$ & $4.94 *$ & $5.95 *$ & $5.07 *$ \\
\hline
\end{tabular}

The entries are average wage or compensation for the relevant group. A box indicates that the averages are significantly different between nonprofit and for-profit sectors at the 5 percent level or less. A star indicates that wage or compensation is different between full-time and part-time in the corresponding row at the 5 percent level or less. 
Table 2

Raw Full-time and Nonprofit Wage and

Compensation Differentials

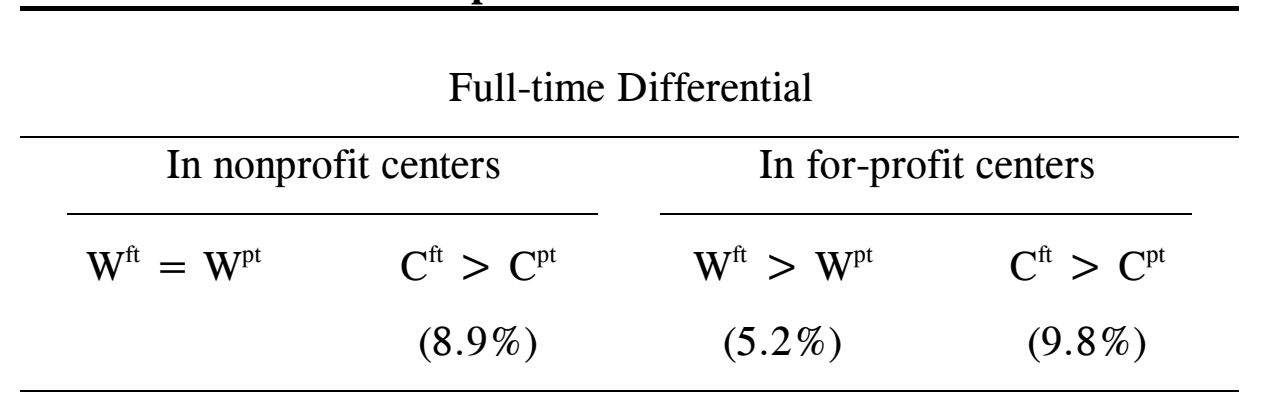

Nonprofit Differential

\begin{tabular}{ccccc}
\hline \multicolumn{2}{c}{ For full-time workers } & & \multicolumn{2}{c}{ For part-time workers } \\
\cline { 1 - 1 } \cline { 5 - 6 } $\mathrm{W}^{\mathrm{np}}>\mathrm{W}^{\mathrm{pr}}$ & $\mathrm{C}^{\mathrm{np}}>\mathrm{C}^{\mathrm{pr}}$ & & $\mathrm{W}^{\mathrm{np}}>\mathrm{W}^{\mathrm{pr}}$ & $\mathrm{C}^{\mathrm{np}}>\mathrm{C}^{\mathrm{pr}}$ \\
$(7.8 \%)$ & $(11.6 \%)$ & & $(11.6 \%)$ & $(13.6 \%)$
\end{tabular}

$W$ stands for wage, $C$ stands for compensation, $f t$ represents full-time, $p t$ represents part-time, $n p$ means nonprofit, and $p r$ is for-profit. 
Table 3

Descriptive Statistics of Workers

\begin{tabular}{|c|c|c|c|}
\hline Variable & Definition & Mean & $\begin{array}{l}\text { Standard } \\
\text { Deviation }\end{array}$ \\
\hline Wage & The hourly pre-tax wage rate. & 6.934 & $(2.582)$ \\
\hline Compensation & The hourly compensation & 8.02 & $(3.20)$ \\
\hline Full -Time & Dummy $(=1)$ if the worker works full-time & 0.646 & $(0.478)$ \\
\hline Female & $\operatorname{Dummy}(=1)$ if female & 0.968 & $(0.176)$ \\
\hline Age & Age of the worker & 33.323 & $(11.644)$ \\
\hline Tenure & Tenure at the center (in months) & 38.123 & $(48.584)$ \\
\hline Experience & Years of experience in early education and child care & 7.726 & $(6.498)$ \\
\hline Other Experience & $\begin{array}{l}\text { Years of total work experience outside early education and } \\
\text { child care }\end{array}$ & 6.701 & $(6.609)$ \\
\hline $\begin{array}{l}\text { Less Than High } \\
\text { School }\end{array}$ & $\operatorname{Dummy}(=1)$ if no high school diploma & 0.026 & $(0.16)$ \\
\hline High School & $\operatorname{Dummy}(=1)$ if high school graduate or GED & 0.187 & $(0.39)$ \\
\hline Some College & $\operatorname{Dummy}(=1)$ if some college courses & 0.339 & $(0.474)$ \\
\hline Community College & Dummy $(=1)$ if two year college degree & 0.142 & $(0.349)$ \\
\hline College & $\operatorname{Dummy}(=1)$ if four year college degree & 0.189 & $(0.392)$ \\
\hline $\begin{array}{l}\text { Some Graduate } \\
\text { School }\end{array}$ & $\operatorname{Dummy}(=1)$ if some graduate school & 0.069 & $(0.253)$ \\
\hline Graduate Degree & $\operatorname{Dummy}(=1)$ if graduate degree & 0.045 & $(0.208)$ \\
\hline No Training & $\begin{array}{l}\text { Dummy }(=1) \text { if no special training in early childhood } \\
\text { education }\end{array}$ & 0.139 & $(0.346)$ \\
\hline Assistant Teacher & $\operatorname{Dummy}(=1)$ if assistant teacher & 0.425 & $(0.495)$ \\
\hline $\begin{array}{l}\text { Infant-Toddler } \\
\text { Room }\end{array}$ & $\begin{array}{l}\operatorname{Dummy}(=1) \text { if the worker works in an infant-toddler } \\
\text { room }\end{array}$ & 0.323 & $(0.468)$ \\
\hline Own Kids & Worker's number of children & 0.985 & $(1.244)$ \\
\hline $\begin{array}{l}\text { Own Kids At } \\
\text { Center }\end{array}$ & $\begin{array}{l}\operatorname{Dummy}(=1) \text { if any of worker's children is cared for in the } \\
\text { same center }\end{array}$ & 0.153 & $(0.36)$ \\
\hline Organization & $\begin{array}{l}\operatorname{Dummy}(=1) \text { if the worker belongs to a professional } \\
\text { organization }\end{array}$ & 0.241 & $(0.428)$ \\
\hline Important Job & $\begin{array}{l}\text { If the worker's main reason to choose employment in child } \\
\text { care is "this is an important job that someone needs to } \\
\text { do." }\end{array}$ & 0.262 & $(0.44)$ \\
\hline Single & $\operatorname{Dummy}(=1)$ if the worker is single & 0.350 & $(0.477)$ \\
\hline Married & $\begin{array}{l}\operatorname{Dummy}(=1) \text { if the worker is married or living with a } \\
\text { significant other }\end{array}$ & 0.545 & $(0.498)$ \\
\hline
\end{tabular}


Table 3 (concluded)

\begin{tabular}{|c|c|c|c|}
\hline White & Dummy $(=1)$ if the worker is white & 0.684 & $(0.465)$ \\
\hline Hispanic & $\operatorname{Dummy}(=1)$ if the worker is Hispanic & 0.115 & $(0.319)$ \\
\hline Black & $\operatorname{Dummy}(=1)$ if the worker is African-American & 0.128 & $(0.334)$ \\
\hline Asian & $\operatorname{Dummy}(=1)$ if the worker is Asian or Pacific Islander & 0.024 & $(0.154)$ \\
\hline Other Race & $\operatorname{Dummy}(=1)$ if the worker is of some other race. & 0.046 & $(0.210)$ \\
\hline Household Income1 & $\begin{array}{l}\text { Dummy }(=1) \text { if the worker's last year's total before-tax } \\
\text { household income }<\$ 10,000\end{array}$ & 0.178 & $(0.383)$ \\
\hline Household Income2 & $\begin{array}{l}\text { Dummy }(=1) \text { if last year's total before-tax household } \\
\text { income is between } \$ 10,000 \text { and } \$ 19,999\end{array}$ & 0.239 & $(0.426)$ \\
\hline Household Income3 & $\begin{array}{l}\text { Dummy }(=1) \text { if last year's total before-tax household } \\
\text { income is between } \$ 20,000 \text { and } \$ 29,999\end{array}$ & 0.172 & $(0.378)$ \\
\hline Household Income4 & $\begin{array}{l}\text { Dummy }(=1) \text { if last year's total before-tax household } \\
\text { income is between } \$ 30,000 \text { and } \$ 39,999\end{array}$ & 0.149 & $(0.356)$ \\
\hline Household Income5 & $\begin{array}{l}\text { Dummy }(=1) \text { if last year's total before-tax household } \\
\text { income is between } \$ 40,000 \text { and } \$ 49,999\end{array}$ & 0.092 & $(0.289)$ \\
\hline Household Income6 & $\begin{array}{l}\text { Dummy }(=1) \text { if last year's total before-tax household } \\
\text { income } \geq \$ 50,000\end{array}$ & 0.171 & $(0.377)$ \\
\hline
\end{tabular}
$\mathrm{N}=1,035$. 
Table 3A

Descriptive Statistics of Workers by Type

\begin{tabular}{|c|c|c|c|c|c|c|c|c|}
\hline \multirow[t]{2}{*}{ Variable } & \multicolumn{2}{|c|}{$\begin{array}{c}\text { For-profit } \\
\text { Workers }\end{array}$} & \multicolumn{2}{|c|}{$\begin{array}{c}\text { Nonprofit } \\
\text { Workers }\end{array}$} & \multicolumn{2}{|c|}{$\begin{array}{l}\text { Full-time } \\
\text { Workers }\end{array}$} & \multicolumn{2}{|c|}{$\begin{array}{l}\text { Part-time } \\
\text { Workers }\end{array}$} \\
\hline & Mean & Std. & Mean & Std. & Mean & Std. & Mean & Std. \\
\hline Full -Time & $0.681 *$ & $(0.467)$ & $0.615^{*}$ & $(0.487)$ & 1.000 & 0.000 & 0.000 & 0.000 \\
\hline Female & 0.978 & $(0.148)$ & 0.959 & $(0.198)$ & 0.969 & $(0.175)$ & 0.967 & $(0.178)$ \\
\hline Age & $31.392 *$ & $(10.96)$ & $35.093 *$ & (11.977) & $32.324 *$ & (11.124) & $35.148^{*}$ & $(12.348)$ \\
\hline Tenure & $30.237 *$ & $(40.751)$ & $45.351 *$ & $(53.82)$ & $35.790^{*}$ & $(45.311)$ & $42.387 *$ & $(53.861)$ \\
\hline Experience & $7.226^{*}$ & $(6.299)$ & $8.184^{*}$ & $(6.649)$ & 7.679 & $(6.346)$ & 7.813 & $(6.776)$ \\
\hline Other Experience & 6.641 & $(6.592)$ & 6.756 & $(6.630)$ & 6.557 & $(6.500)$ & 6.963 & $(6.804)$ \\
\hline Less Than High School & $0.016^{*}$ & $(0.126)$ & $0.035^{*}$ & $(0.184)$ & 0.019 & $(0.138)$ & 0.038 & $(0.192)$ \\
\hline High School & 0.190 & $(0.393)$ & 0.183 & $(0.387)$ & 0.188 & $(0.391)$ & 0.183 & $(0.387)$ \\
\hline Some College & 0.331 & $(0.471)$ & 0.346 & $(0.476)$ & 0.339 & $(0.474)$ & 0.339 & $(0.474)$ \\
\hline Community College & 0.131 & $(0.338)$ & 0.152 & $(0.359)$ & 0.149 & $(0.357)$ & 0.128 & $(0.335)$ \\
\hline College & $0.232 *$ & $(0.423)$ & $0.150 *$ & $(0.357)$ & 0.196 & $(0.397)$ & 0.178 & $(0.383)$ \\
\hline Some Graduate School & $0.053 *$ & $(0.223)$ & $0.083 *$ & $(0.277)$ & 0.064 & $(0.245)$ & 0.077 & $(0.266)$ \\
\hline Graduate Degree & 0.046 & $(0.211)$ & 0.044 & $(0.206)$ & 0.040 & $(0.197)$ & 0.055 & $(0.228)$ \\
\hline No Training & 0.141 & $(0.349)$ & 0.137 & $(0.344)$ & 0.136 & $(0.343)$ & 0.145 & $(0.352)$ \\
\hline Assistant Teacher & $0.386^{*}$ & $(0.487)$ & $0.461 *$ & $(0.499)$ & $0.360^{*}$ & $(0.480)$ & $0.544^{*}$ & $(0.499)$ \\
\hline Infant-Toddler Room & $0.410^{*}$ & $(0.492)$ & $0.243 *$ & $(0.429)$ & $0.357 *$ & $(0.480)$ & $0.260^{*}$ & $(0.439)$ \\
\hline Own Kids & $0.857^{*}$ & $(1.221)$ & $1.102 *$ & $(1.254)$ & $0.892 *$ & $(1.178)$ & $1.153^{*}$ & $(1.342)$ \\
\hline Own Kids at Center & $0.200^{*}$ & $(0.400)$ & $0.109^{*}$ & $(0.312)$ & 0.160 & $(0.367)$ & 0.139 & $(0.347)$ \\
\hline Organization & $0.176^{*}$ & $(0.381)$ & $0.302 *$ & $(0.459)$ & 0.233 & $(0.423)$ & 0.257 & $(0.437)$ \\
\hline Important Job & 0.240 & $(0.428)$ & 0.281 & $(0.450)$ & 0.268 & $(0.443)$ & 0.251 & $(0.434)$ \\
\hline Single & 0.378 & $(0.485)$ & 0.324 & $(0.468)$ & $0.383^{*}$ & $(0.486)$ & $0.290^{*}$ & $(0.454)$ \\
\hline Married & 0.535 & $(0.499)$ & 0.554 & $(0.498)$ & $0.511^{*}$ & $(0.500)$ & $0.607 *$ & $(0.489)$ \\
\hline Hispanic & $0.085^{*}$ & $(0.279)$ & $0.143^{*}$ & $(0.350)$ & 0.120 & $(0.325)$ & 0.107 & $(0.309)$ \\
\hline Black & $0.079^{*}$ & $(0.270)$ & $0.172 *$ & $(0.378)$ & $0.142 *$ & $(0.349)$ & $0.101 *$ & $(0.302)$ \\
\hline Asian & 0.028 & $(0.166)$ & 0.020 & $(0.141)$ & 0.018 & $(0.133)$ & 0.036 & $(0.185)$ \\
\hline Other Race & 0.055 & $(0.227)$ & 0.039 & $(0.194)$ & 0.042 & $(0.200)$ & 0.055 & $(0.228)$ \\
\hline Household Income1 & 0.188 & $(0.391)$ & 0.169 & $(0.375)$ & $0.194 *$ & $(0.396)$ & $0.148^{*}$ & $(0.355)$ \\
\hline Household Income2 & 0.234 & $(0.424)$ & 0.243 & $(0.429)$ & $0.277^{*}$ & $(0.448)$ & $0.169^{*}$ & $(0.376)$ \\
\hline Household Income3 & 0.152 & $(0.359)$ & 0.191 & $(0.393)$ & 0.185 & $(0.389)$ & 0.148 & $(0.355)$ \\
\hline Household Income4 & 0.154 & $(0.361)$ & 0.144 & $(0.352)$ & 0.138 & $(0.345)$ & 0.169 & $(0.376)$ \\
\hline
\end{tabular}




\begin{tabular}{lcccc|cccc}
\multicolumn{8}{c}{ (Table 3A concluded) } \\
Household Income5 & 0.085 & $(0.279)$ & 0.098 & $(0.298)$ & 0.082 & $(0.275)$ & 0.109 & $(0.312)$ \\
Household Income6 & 0.188 & $(0.391)$ & 0.156 & $(0.363)$ & $0.124^{*}$ & $(0.330)$ & $0.257^{*}$ & $(0.437)$ \\
\hline $\mathrm{N}$ & 495 & \multicolumn{3}{c|}{540} & 669 & \multicolumn{3}{c}{366} \\
\hline $\begin{array}{l}* \text { indicates statistically significant differences in means between for-profit and nonprofit or full-time and part-time } \\
\text { workers. }\end{array}$
\end{tabular}


Table 4

Center Characteristics

\begin{tabular}{|c|c|c|c|}
\hline Variable & Definition & Mean & $\begin{array}{l}\text { Standard } \\
\text { Deviation }\end{array}$ \\
\hline For-Profit & Dummy $(=1)$ if the center if for-profit & 0.478 & $(0.500)$ \\
\hline National Chain & $\begin{array}{l}\text { Dummy variable }(=1) \text { if center is member of a } \\
\text { national chain. }\end{array}$ & 0.123 & $(0.328)$ \\
\hline On-Site & $\begin{array}{l}\text { Dummy variable }(=1) \text { if center is a worksite child } \\
\text { care center. }\end{array}$ & 0.050 & $(0.219)$ \\
\hline Publicly Regulated & $\begin{array}{l}\text { Dummy variable }(=1) \text { if center receives public } \\
\text { money tied to higher standards, }(=0) \text { otherwise. }\end{array}$ & 0.065 & $(0.246)$ \\
\hline Publicly Owned & $\begin{array}{l}\text { Dummy variable }(=1) \text { if center is publicly owned } \\
\text { and operated, }(=0) \text { otherwise. }\end{array}$ & 0.081 & $(0.273)$ \\
\hline Publicly Supported & $\begin{array}{l}\text { Dummy variable }(=1) \text { if center is not public } 1 y \\
\text { owned or operated, but receives more than } 50 \\
\text { percent of its revenue from public grants, fees and } \\
\text { USDA reimbursement, }(=0) \text { otherwise }\end{array}$ & 0.079 & $(0.270)$ \\
\hline Religious & $\begin{array}{l}\text { Dummy variable }(=1) \text { if center is religiously } \\
\text { affiliated, }(=0) \text { otherwise }\end{array}$ & 0.213 & $(0.409)$ \\
\hline Union & $\begin{array}{l}\text { Dummy variable }(=1) \text { if center workers are } \\
\text { unionized. }\end{array}$ & 0.059 & $(0.236)$ \\
\hline Percent Subsidized & The proportion of children that are subsidized. & 0.207 & $(0.307)$ \\
\hline Center Age & Number of years that center has been in operation. & 13.412 & $(13.824)$ \\
\hline Part-Week & Dummy $(=1)$ if part-week program & 0.800 & $(0.400)$ \\
\hline Extended Care & $\operatorname{Dummy}(=1)$ if part-day extended care program & 0.586 & $(0.493)$ \\
\hline Head Start & Dummy $(=1)$ if Head Start program & 0.021 & $(0.144)$ \\
\hline Before And After School & $\begin{array}{l}\operatorname{Dummy}(=1) \text { if center provides before and after } \\
\text { school care }\end{array}$ & 0.573 & $(0.495)$ \\
\hline Summer Camp & $\begin{array}{l}\operatorname{Dummy}(=1) \text { if center provides summer camp } \\
\text { programs for school-agers }\end{array}$ & 0.476 & $(0.500)$ \\
\hline Evening Care & $\operatorname{Dummy}(=1)$ if center provides evening care & 0.041 & $(0.197)$ \\
\hline Weekend Care & $\operatorname{Dummy}(=1)$ if center provides weekend care & 0.018 & $(0.134)$ \\
\hline Sick Care & $\operatorname{Dummy}(=1)$ if center provides sick care & 0.029 & $(0.168)$ \\
\hline 24-Hour Care & $\operatorname{Dummy}(=1)$ if center provides 24 hour care & 0.002 & $(0.044)$ \\
\hline FTE Children & Full-time equivalent children at the center & 74.133 & $(47.104)$ \\
\hline Unemployment & $\begin{array}{l}\text { The unemployment rate in the city where the } \\
\text { center is located in } 1992\end{array}$ & 6.970 & $(2.060)$ \\
\hline
\end{tabular}


Table 4 (concluded)

$\begin{array}{llll}\text { California } & \text { Dummy }(=1) \text { if the center is in California. } & 0.270 & (0.444) \\ \text { Colorado } & \text { Dummy }(=1) \text { if the center is in Colorado. } & 0.275 & (0.447) \\ \text { Connecticut } & \text { Dummy }(=1) \text { if the center is in Connecticut. } & 0.242 & (0.429) \\ \text { North Carolina } & \text { Dummy }(=1) \text { if the center is in North Carolina. } & 0.213 & (0.409)\end{array}$


Table 5

Estimated Selection Equations

System with Wage Equations

\begin{tabular}{|c|c|c|}
\hline Variable & $\begin{array}{l}\text { Selection into for- } \\
\text { profit }\end{array}$ & $\begin{array}{l}\text { Selection into full-time } \\
\text { Work }\end{array}$ \\
\hline Constant & $\begin{array}{l}-0.392 \\
(0.255)\end{array}$ & $\begin{array}{l}-0.059 \\
(0.162)\end{array}$ \\
\hline Tenure & $\begin{array}{c}-0.002 * * \\
(0.001)\end{array}$ & $\begin{array}{l}0.001 * * \\
(0.0005)\end{array}$ \\
\hline Experience & $\begin{array}{c}0.001 \\
(0.005)\end{array}$ & $\begin{array}{l}0.014 * * \\
(0.003)\end{array}$ \\
\hline Other Experience & $\begin{array}{l}-0.001 \\
(0.004)\end{array}$ & $\begin{array}{c}0.003 \\
(0.002)\end{array}$ \\
\hline Female & $\begin{array}{c}0.179 \\
(0.116)\end{array}$ & $\begin{array}{l}-0.088 \\
(0.073)\end{array}$ \\
\hline High School & $\begin{array}{l}0.224 \\
(0.16)\end{array}$ & $\begin{array}{l}0.390 * * \\
(0.088)\end{array}$ \\
\hline Some College & $\begin{array}{c}-0.02 \\
(0.159)\end{array}$ & $\begin{array}{c}0.518 * * \\
(0.08)\end{array}$ \\
\hline Community College & $\begin{array}{c}0.051 \\
(0.173)\end{array}$ & $\begin{array}{c}0.490 * * \\
(0.100)\end{array}$ \\
\hline College & $\begin{array}{l}0.291 \\
(0.16)\end{array}$ & $\begin{array}{l}0.561 * * \\
(0.093)\end{array}$ \\
\hline Some Graduate School & $\begin{array}{c}0.076 \\
(0.179)\end{array}$ & $\begin{array}{l}0.309 * * \\
(0.106)\end{array}$ \\
\hline Graduate Degree & $\begin{array}{l}0.470^{*} \\
(0.207)\end{array}$ & $\begin{array}{c}0.664 * * \\
(0.116)\end{array}$ \\
\hline No Training & $\begin{array}{l}-0.007 \\
(0.074)\end{array}$ & $\begin{array}{l}-0.059 \\
(0.052)\end{array}$ \\
\hline Single & $\begin{array}{l}-0.203^{*} \\
(0.098)\end{array}$ & $\begin{array}{l}0.112 * * \\
(0.057)\end{array}$ \\
\hline Married & $\begin{array}{l}-0.178^{*} \\
(0.088)\end{array}$ & $\begin{array}{l}-0.003 \\
(0.056)\end{array}$ \\
\hline White & $\begin{array}{l}-0.132 \\
(0.094)\end{array}$ & $\begin{array}{c}0.083 \\
(0.066)\end{array}$ \\
\hline Hispanic & $\begin{array}{c}-0.451 * * \\
(0.104)\end{array}$ & $\begin{array}{c}0.225 * * \\
(0.078)\end{array}$ \\
\hline Black & $\begin{array}{c}-0.346^{* *} \\
(0.122)\end{array}$ & $\begin{array}{l}0.310 * * \\
(0.073)\end{array}$ \\
\hline Asian & $\begin{array}{l}-0.132 \\
(0.192)\end{array}$ & $\begin{array}{l}-0.139 \\
(0.089)\end{array}$ \\
\hline Organization & $\begin{array}{c}-0.423 * * \\
(0.058)\end{array}$ & $\begin{array}{l}-0.015 \\
(0.043)\end{array}$ \\
\hline Important Job & $\begin{array}{l}-0.101 \\
(0.055)\end{array}$ & $\begin{array}{c}0.069 \\
(0.043)\end{array}$ \\
\hline Part-Week & $\begin{array}{c}-0.252 * * \\
(0.068)\end{array}$ & $\begin{array}{l}-0.102 \\
(0.056)\end{array}$ \\
\hline Extended Care & $\begin{array}{c}0.626 * * \\
(0.072)\end{array}$ & $\begin{array}{c}-0.168 * * \\
(0.048)\end{array}$ \\
\hline
\end{tabular}


Head Start

Before And After School

Summer Camp

Evening Care

Sick Care

24-Hour Care

Unemployment

Percent Subsidized

Center Age

FTE Children

Household Income1

Household Income2

Household Income3

Household Income4

Household Income5

Union

Own Kids

Own Kids At Center

California

Colorado

Connecticut

(Table 5 concluded)

\begin{tabular}{|c|c|}
\hline-- & $\begin{array}{c}0.199 \\
(0.154)\end{array}$ \\
\hline $.467 * *$ & 0.001 \\
\hline (0.075) & $(0.047)$ \\
\hline $0.177 * *$ & $-0.128 *$ \\
\hline (0.067) & $(0.054)$ \\
\hline $0.282 *$ & 0.186 \\
\hline$(0.112)$ & $(0.104)$ \\
\hline 0.198 & 0.178 \\
\hline (0.226) & $(0.135)$ \\
\hline-- & $\begin{array}{c}-0.706^{* *} \\
(0.171)\end{array}$ \\
\hline 0.008 & $-0.038 * *$ \\
\hline (0.015) & $(0.008)$ \\
\hline $1.272 * *$ & $-0.240 *$ \\
\hline$(0.123)$ & $(0.067)$ \\
\hline $0.034 * *$ & -0.002 \\
\hline$(0.003)$ & $(0.002)$ \\
\hline $0.003 * *$ & -- \\
\hline (0.001) & \\
\hline 0.061 & $0.389 * *$ \\
\hline (0.087) & $(0.069)$ \\
\hline-0.036 & $0.624 * *$ \\
\hline (0.073) & $(0.061)$ \\
\hline $0.259 * *$ & $0.511 * *$ \\
\hline$(0.072)$ & $(0.059)$ \\
\hline 0.004 & $0.270 * *$ \\
\hline (0.072) & $(0.054)$ \\
\hline-0.137 & $0.152 *$ \\
\hline (0.093) & $(0.065)$ \\
\hline-- & $-0.132 *$ \\
\hline & $(0.067)$ \\
\hline $0.092 * *$ & $-0.045 * *$ \\
\hline$(0.024)$ & $(0.016)$ \\
\hline $.432 * *$ & -- \\
\hline$(0.07)$ & \\
\hline $0.342 * *$ & $-0.245^{* *}$ \\
\hline (0.099) & $(0.073)$ \\
\hline-0.055 & 0.105 \\
\hline (0.087) & $(0.076)$ \\
\hline $.331 * *$ & $-0.271 * *$ \\
\hline (0.092) & $(0.068)$ \\
\hline
\end{tabular}

$(0.154)$

$(0.047)$

$-0.128^{*}$

$0.054)$

$0.104)$

0.178

$(0.135)$

$(0.171)$

$-0.038 * *$

$240 *$

(0.067)

$-0.002$

$.389 * *$

(2)

(0.061)

$.511 * *$

(0.059)

$.270 * *$

$(0.054)$

$0.152 *$

.065)

$0.067)$

$-0.045 * *$

$-$

(0.068)

See the notes to Table 6 . 
Table 6

Estimated Wage Equations

\begin{tabular}{|c|c|c|c|c|}
\hline Variable & $\begin{array}{l}\text { For-profit } \\
\text { Full-time }\end{array}$ & $\begin{array}{l}\text { Nonprofit } \\
\text { Full-time }\end{array}$ & $\begin{array}{l}\text { For-profit } \\
\text { Part-time } \\
\end{array}$ & $\begin{array}{l}\text { Nonprofit } \\
\text { Part-time }\end{array}$ \\
\hline \multirow[t]{2}{*}{ Constant } & $1.551 * *$ & $1.561 * *$ & $1.564 * *$ & $1.696 * *$ \\
\hline & $(0.060)$ & $(0.059)$ & $(0.104)$ & $(0.013)$ \\
\hline \multirow[t]{2}{*}{ Tenure } & $0.001 * *$ & $0.0004 *$ & $0.002 * *$ & $0.002 * *$ \\
\hline & $(0.0002)$ & $(0.0002)$ & $(0.0003)$ & $(0.0004)$ \\
\hline \multirow[t]{2}{*}{ Experience } & $0.003 * *$ & $0.010 * *$ & $0.003 *$ & $0.006 * *$ \\
\hline & $(0.001)$ & $(0.001)$ & $(0.001)$ & $(0.0003)$ \\
\hline \multirow[t]{2}{*}{ Other Experience } & $0.003 * *$ & $0.002 *$ & -0.001 & $0.005 * *$ \\
\hline & $(0.0005)$ & $(0.001)$ & $(0.001)$ & $(0.0001)$ \\
\hline \multirow[t]{2}{*}{ Female } & 0.009 & -0.037 & $-0.110 *$ & $-0.042 * *$ \\
\hline & $(0.019)$ & $(0.021)$ & $(0.047)$ & $(0.006)$ \\
\hline \multirow[t]{2}{*}{ High School } & -0.022 & 0.016 & $0.211 * *$ & $0.170 * *$ \\
\hline & $(0.021)$ & $(0.029)$ & $(0.029)$ & $(0.006)$ \\
\hline \multirow[t]{2}{*}{ Some College } & 0.026 & 0.017 & $0.290 * *$ & $0.235^{* *}$ \\
\hline & $(0.023)$ & $(0.025)$ & $(0.030)$ & $(0.005)$ \\
\hline \multirow[t]{2}{*}{ Community College } & $0.051 *$ & $0.107 * *$ & $0.405^{* *}$ & $0.180 * *$ \\
\hline & $(0.020)$ & $(0.029)$ & $(0.035)$ & $(0.006)$ \\
\hline \multirow[t]{2}{*}{ College } & $0.088 * *$ & $0.191 * *$ & $0.371 * *$ & $0.318 * *$ \\
\hline & $(0.022)$ & $(0.034)$ & $(0.029)$ & $(0.007)$ \\
\hline \multirow[t]{2}{*}{ Some Graduate School } & $0.147 * *$ & $0.179 * *$ & $0.386 * *$ & $0.253 * *$ \\
\hline & $(0.037)$ & $(0.030)$ & $(0.04)$ & $(0.008)$ \\
\hline \multirow[t]{2}{*}{ Graduate Degree } & 0.036 & $0.357 * *$ & $0.370 * *$ & $0.452 * *$ \\
\hline & $(0.030)$ & $(0.041)$ & $(0.040)$ & $(0.007)$ \\
\hline \multirow[t]{2}{*}{ No Training } & $-0.039 *$ & $-0.074 * *$ & $-0.037 *$ & $-0.086 * *$ \\
\hline & $(0.020)$ & $(0.019)$ & $(0.018)$ & $(0.004)$ \\
\hline \multirow[t]{2}{*}{ White } & $0.063 * *$ & 0.055 & 0.025 & $-0.018 * *$ \\
\hline & $(0.020)$ & $(0.039)$ & $(0.021)$ & $(0.006)$ \\
\hline \multirow[t]{2}{*}{ Hispanic } & $0.059 *$ & $0.078 *$ & 0.067 & $0.020 * *$ \\
\hline & $(0.025)$ & $(0.037)$ & $(0.038)$ & $(0.006)$ \\
\hline \multirow[t]{2}{*}{ Black } & $0.068 *$ & 0.052 & $0.074 *$ & $0.025 * *$ \\
\hline & $(0.032)$ & $(0.037)$ & $(0.029)$ & $(0.008)$ \\
\hline \multirow[t]{2}{*}{ Asian } & -0.056 & 0.049 & -0.058 & $-0.131 * *$ \\
\hline & $(0.056)$ & $(0.071)$ & $(0.033)$ & $(0.009)$ \\
\hline \multirow[t]{2}{*}{ Organization } & $0.069 * *$ & $0.049 * *$ & -0.028 & $0.085 * *$ \\
\hline & $(0.014)$ & $(0.015)$ & $(0.018)$ & $(0.003)$ \\
\hline \multirow[t]{2}{*}{ Important Job } & $0.024 *$ & $-0.047 * *$ & 0.031 & $-0.024 * *$ \\
\hline & $(0.012)$ & $(0.014)$ & $(0.021)$ & $(0.002)$ \\
\hline \multirow[t]{2}{*}{ Assistant Teacher } & $-0.074 * *$ & $-0.092 * *$ & $-0.106 * *$ & $-0.146^{* *}$ \\
\hline & $(0.012)$ & $(0.015)$ & $(0.014)$ & $(0.003)$ \\
\hline \multirow[t]{2}{*}{ Infant-Toddler Room } & $-0.022 *$ & -0.013 & $-0.060 * *$ & $-0.029 * *$ \\
\hline & $(0.011)$ & $(0.014)$ & $(0.013)$ & $(0.005)$ \\
\hline \multirow[t]{2}{*}{ On-Site } & $0.233 * *$ & $0.195 * *$ & $0.137 * *$ & $0.372 * *$ \\
\hline & $(0.070)$ & $(0.030)$ & $(0.037)$ & $(0.007)$ \\
\hline \multirow[t]{2}{*}{ National Chain } & $-0.057 * *$ & -- & $-0.117 * *$ & -- \\
\hline & $(0.012)$ & & $(0.018)$ & \\
\hline \multirow[t]{2}{*}{ Publicly Supported } & 0.012 & $-0.124 * *$ & -0.026 & $0.062 * *$ \\
\hline & $(0.071)$ & $(0.025)$ & $(0.076)$ & $(0.006)$ \\
\hline
\end{tabular}




\begin{tabular}{|c|c|c|c|c|}
\hline \multirow[b]{2}{*}{ Publicly Owned } & & \multirow[b]{2}{*}{--} & \multirow[b]{2}{*}{$\begin{array}{c}0.118 * * \\
(0.006)\end{array}$} \\
\hline & -- & $\begin{array}{c}0.148 * * \\
(0.029)\end{array}$ & & \\
\hline Publicly Regulated & -- & $\begin{array}{c}0.188 * * \\
(0.030)\end{array}$ & -- & $\begin{array}{c}-0.031^{* *} \\
(0.005)\end{array}$ \\
\hline Religious & -- & $\begin{array}{c}-0.041^{*} \\
(0.017)\end{array}$ & -- & $\begin{array}{c}-0.029 * * \\
(0.004)\end{array}$ \\
\hline Union & -- & $\begin{array}{c}0.219 * * \\
(0.035)\end{array}$ & -- & $\begin{array}{c}0.220 * * \\
(0.003)\end{array}$ \\
\hline Unemployment & $\begin{array}{c}0.004 \\
(0.004)\end{array}$ & $\begin{array}{c}0.006 \\
(0.004)\end{array}$ & $\begin{array}{l}-0.010 \\
(0.006)\end{array}$ & $\begin{array}{c}-0.002 * \\
(0.001)\end{array}$ \\
\hline FTE Children & $\begin{array}{l}0.001 * * \\
(0.0001)\end{array}$ & $\begin{array}{c}-0.0004 * * \\
(0.0002)\end{array}$ & $\begin{array}{l}0.0004 * \\
(0.0002)\end{array}$ & $\begin{array}{l}-0.001 * * \\
(0.0001)\end{array}$ \\
\hline Percent Subsidized & $\begin{array}{c}-0.046 \\
(0.054)\end{array}$ & $\begin{array}{c}-0.081 * * \\
(0.030)\end{array}$ & $\begin{array}{l}-0.125^{*} \\
(0.062)\end{array}$ & $\begin{array}{c}-0.139 * * \\
(0.005)\end{array}$ \\
\hline Center Age & $\begin{array}{c}-0.001 \\
(0.001)\end{array}$ & $\begin{array}{l}-0.001 * \\
(0.0004)\end{array}$ & $\begin{array}{c}0.003 * * \\
(0.001)\end{array}$ & $\begin{array}{l}0.002 * * \\
(0.0001)\end{array}$ \\
\hline Part-Week & $\begin{array}{c}0.016 \\
(0.023)\end{array}$ & $\begin{array}{c}-0.051 * * \\
(0.018)\end{array}$ & $\begin{array}{l}-0.069 \\
(0.043)\end{array}$ & $\begin{array}{c}-0.069 * * \\
(0.004)\end{array}$ \\
\hline Extended Care & $\begin{array}{c}-0.018 \\
(0.014)\end{array}$ & $\begin{array}{c}0.058 * * \\
(0.017)\end{array}$ & $\begin{array}{l}-0.003 \\
(0.029)\end{array}$ & $\begin{array}{c}0.087 * * \\
(0.003)\end{array}$ \\
\hline Head Start & -- & $\begin{array}{c}-0.245^{* *} \\
(0.029)\end{array}$ & -- & $\begin{array}{c}0.068 * * \\
(0.013)\end{array}$ \\
\hline Before And After School & $\begin{array}{c}-0.067 * * \\
(0.015)\end{array}$ & $\begin{array}{c}0.009 \\
(0.021)\end{array}$ & $\begin{array}{l}0.054 * \\
(0.024)\end{array}$ & $\begin{array}{l}0.009 * \\
(0.004)\end{array}$ \\
\hline Summer Camp & $\begin{array}{l}-0.009 \\
(0.012)\end{array}$ & $\begin{array}{c}0.016 \\
(0.017)\end{array}$ & $\begin{array}{c}0.033 \\
(0.020)\end{array}$ & $\begin{array}{c}0.055^{* *} \\
(0.004)\end{array}$ \\
\hline Evening Care & $\begin{array}{c}-0.038 \\
(0.029)\end{array}$ & $\begin{array}{c}0.127 * * \\
(0.029)\end{array}$ & $\begin{array}{c}-0.243 * * \\
(0.049)\end{array}$ & $\begin{array}{c}0.106^{* *} \\
(0.014)\end{array}$ \\
\hline Sick Care & $\begin{array}{c}0.020 \\
(0.114)\end{array}$ & $\begin{array}{c}0.012 \\
(0.029)\end{array}$ & $\begin{array}{c}0.070 \\
(0.086)\end{array}$ & $\begin{array}{c}0.114 * * \\
(0.011)\end{array}$ \\
\hline 24-Hour Care & $\begin{array}{c}0.146 \\
(0.156)\end{array}$ & -- & $\begin{array}{c}0.334 * * \\
(0.095)\end{array}$ & -- \\
\hline Own Kids At Center & $\begin{array}{c}0.015 \\
(0.013)\end{array}$ & $\begin{array}{c}0.009 \\
(0.018)\end{array}$ & $\begin{array}{l}-0.020 \\
(0.014)\end{array}$ & $\begin{array}{c}0.039 * * \\
(0.005)\end{array}$ \\
\hline California & $\begin{array}{c}0.267 * * \\
(0.021)\end{array}$ & $\begin{array}{c}0.256^{* *} \\
(0.026)\end{array}$ & $\begin{array}{c}0.327 * * \\
(0.031)\end{array}$ & $\begin{array}{c}0.206 * * \\
(0.007)\end{array}$ \\
\hline Colorado & $\begin{array}{l}0.059 * \\
(0.025)\end{array}$ & $\begin{array}{c}0.071 * * \\
(0.021)\end{array}$ & $\begin{array}{c}0.154 * * \\
(0.036)\end{array}$ & $\begin{array}{c}0.042 * * \\
(0.007)\end{array}$ \\
\hline Connecticut & $\begin{array}{c}0.273 * * \\
(0.020)\end{array}$ & $\begin{array}{c}0.243 * * \\
(0.031)\end{array}$ & $\begin{array}{c}0.247 * * \\
(0.034)\end{array}$ & $\begin{array}{c}0.234 * * \\
(0.006)\end{array}$ \\
\hline & $\mathrm{N}=1,035$ & Log-likelih & $=-1,413.17$ & \\
\hline
\end{tabular}

Estimated standard errors of the coefficients are in parentheses.

* indicates statistical significance between $5 \%$ and $1 \%$.

** indicates statistical significance at the $1 \%$ level or better. 


\section{Table 7}

\begin{tabular}{|c|c|c|}
\hline & Hypotheses & t-statistic \\
\hline I & $\begin{array}{l}\text { For Full-time workers, returns to } \ldots \\
\text { Tenure }-\mathrm{Pr}=\mathrm{Tenure}-\mathrm{Np} \\
\text { Experience }-\mathrm{Pr}=\mathrm{Experience}-\mathrm{Np} \\
\text { Other Experience-Pr }=\text { Other Experience }-\mathrm{Np} \\
\text { High School }-\mathrm{Pr}=\mathrm{High} \text { School }-\mathrm{Np} \\
\text { Community College }-\mathrm{Pr}=\mathrm{Community} \mathrm{College}-\mathrm{Np} \\
\text { College }-\mathrm{Pr}=\text { College }-\mathrm{Np} \\
\text { Graduate Degree }-\mathrm{Pr}=\mathrm{Graduate} \text { Degree-Np } \\
\text { Special Training }-\mathrm{Pr}=\text { Special Training }-\mathrm{Np}{ }^{\text {a }}\end{array}$ & $\begin{array}{c}3.627 \\
-4.129 \\
0.599 \\
-1.078 \\
-1.671 \\
-2.661 \\
-6.521 \\
1.271\end{array}$ \\
\hline II & $\begin{array}{l}\text { For Part-time workers, returns to } . . . \\
\text { Tenure }-\mathrm{Pr}=\mathrm{Tenure}-\mathrm{Np} \\
\text { Experience }-\mathrm{Pr}=\mathrm{Experience}-\mathrm{Np} \\
\text { Other Experience }-\mathrm{Pr}=\text { Other Experience }-\mathrm{Np} \\
\text { High School }-\mathrm{Pr}=\mathrm{High} \text { School }-\mathrm{Np} \\
\text { Community College }-\mathrm{Pr}=\text { Community College }-\mathrm{Np} \\
\text { College- } \mathrm{Pr}=\mathrm{College}-\mathrm{Np} \\
\text { Graduate Degree }-\mathrm{Pr}=\mathrm{Graduate} \text { Degree }-\mathrm{Np} \\
\text { Special Training }-\mathrm{Pr}=\text { Special Training }-\mathrm{Np}{ }^{a}\end{array}$ & $\begin{array}{c}0.863 \\
-2.702 \\
-4.913 \\
1.379 \\
6.287 \\
1.761 \\
-2.029 \\
2.582\end{array}$ \\
\hline III & $\begin{array}{l}\text { In For-profit centers, returns to } \ldots \\
\text { Tenure }-\mathrm{Ft}=\mathrm{Tenure}-\mathrm{Pt} \\
\text { Experience }-\mathrm{Ft}, \mathrm{Pr}=\mathrm{Experience}-\mathrm{Pt}, \mathrm{Pr} \\
\text { Other Experience }-\mathrm{Ft}, \mathrm{Pr}=\text { Other Experience }-\mathrm{Pt}, \mathrm{Pr} \\
\text { High School }-\mathrm{Ft}=\mathrm{High} \text { School }-\mathrm{Pt} \\
\text { Community College }-\mathrm{Ft}=\mathrm{Community} \text { College }-\mathrm{Pt} \\
\text { College }-\mathrm{Ft}=\mathrm{College}-\mathrm{Pt} \\
\text { Graduate Degree }-\mathrm{Ft}=\mathrm{Graduate} \text { Degree }-\mathrm{Pt} \\
\text { Special Training }-\mathrm{Ft}=\text { Special Training }-\mathrm{Pt}^{\mathrm{a}}\end{array}$ & $\begin{array}{c}-0.972 \\
0.423 \\
2.599 \\
-6.348 \\
-8.584 \\
-7.558 \\
-6.488 \\
-0.061\end{array}$ \\
\hline IV & $\begin{array}{l}\text { In Nonprofit centers, returns to } \ldots \\
\text { Tenure }-\mathrm{Ft}=\mathrm{Tenure}-\mathrm{Pt} \\
\text { Experience }-\mathrm{Ft}=\mathrm{Experience}-\mathrm{Pt} \\
\text { Other Experience }-\mathrm{Ft}=\text { Other Experience }-\mathrm{Pt} \\
\text { High School }-\mathrm{Ft}=\mathrm{High} \text { School }-\mathrm{Pt} \\
\text { Community College }-\mathrm{Ft}=\mathrm{Community} \text { College }-\mathrm{Pt} \\
\text { College }-\mathrm{Ft}=\mathrm{College}-\mathrm{Pt} \\
\text { Graduate Degree }-\mathrm{Ft}=\mathrm{Graduate} \text { Degree }-\mathrm{Pt} \\
\text { Special Training }-\mathrm{Ft}=\text { Special Training }-\mathrm{Pt}{ }^{\mathrm{a}}\end{array}$ & $\begin{array}{c}-6.252 \\
2.820 \\
-2.980 \\
-5.231 \\
-2.444 \\
-3.735 \\
-2.239 \\
0.683\end{array}$ \\
\hline
\end{tabular}

Pr stands for For-profit, Np is nonprofit, FT stands for full-time, Pt is part-time.

${ }^{a}$ Because the coefficient of special training is negative in al wage equations, a negative value for the $t$-statistic indicates that the first coefficient is greater than the second one in absolute value. 
Table 8

Selection Equations

System with Compensation

\begin{tabular}{|c|c|c|}
\hline Variable & Selection into for-profit & Selection into full-time \\
\hline Constant & $\begin{array}{l}-0.433 \\
(0.381)\end{array}$ & $\begin{array}{l}-1.245 \\
(1.249)\end{array}$ \\
\hline Tenure & $\begin{array}{l}-0.002 * \\
(0.001)\end{array}$ & $\begin{array}{c}0.025 * * \\
(0.003)\end{array}$ \\
\hline Experience & $\begin{array}{l}-0.003 \\
(0.007)\end{array}$ & $\begin{array}{c}0.122 * * \\
(0.019)\end{array}$ \\
\hline Other Experience & $\begin{array}{c}0.002 \\
(0.005)\end{array}$ & $\begin{array}{l}-0.017 \\
(0.015)\end{array}$ \\
\hline Female & $\begin{array}{c}0.356 \\
(0.201)\end{array}$ & $\begin{array}{c}2.311 * * \\
(0.604)\end{array}$ \\
\hline High School & $\begin{array}{c}0.297 \\
(0.195)\end{array}$ & $\begin{array}{c}6.669 * * \\
(0.469)\end{array}$ \\
\hline Some College & $\begin{array}{c}0.082 \\
(0.185)\end{array}$ & $\begin{array}{c}6.301 * * \\
(0.441)\end{array}$ \\
\hline Community College & $\begin{array}{c}0.128 \\
(0.193)\end{array}$ & $\begin{array}{c}10.145^{* *} \\
(0.540)\end{array}$ \\
\hline College & $\begin{array}{c}0.544 * * \\
(0.205)\end{array}$ & $\begin{array}{c}3.991 * * \\
(0.481)\end{array}$ \\
\hline Some Graduate School & $\begin{array}{c}0.141 \\
(0.247)\end{array}$ & $\begin{array}{c}6.023 * * \\
(0.639)\end{array}$ \\
\hline Graduate Degree & $\begin{array}{l}0.646^{*} \\
(0.287)\end{array}$ & $\begin{array}{c}5.382 * * \\
(0.591)\end{array}$ \\
\hline No Training & $\begin{array}{c}-0.181 \\
(0.094)\end{array}$ & $\begin{array}{c}0.769 * * \\
(0.277)\end{array}$ \\
\hline Single & $\begin{array}{c}-0.255^{*} \\
(0.114)\end{array}$ & $\begin{array}{c}2.722 * * \\
(0.386)\end{array}$ \\
\hline Married & $\begin{array}{c}-0.301 * * \\
(0.108)\end{array}$ & $\begin{array}{c}2.738 * * \\
(0.357)\end{array}$ \\
\hline White & $\begin{array}{c}0.080 \\
(0.150)\end{array}$ & $\begin{array}{c}-4.256^{* *} \\
(0.381)\end{array}$ \\
\hline Hispanic & $\begin{array}{c}-0.358^{*} \\
(0.170)\end{array}$ & $\begin{array}{c}0.220 \\
(0.477)\end{array}$ \\
\hline Black & $\begin{array}{c}-0.204 \\
(0.170)\end{array}$ & $\begin{array}{c}-6.826^{* *} \\
(0.411)\end{array}$ \\
\hline Asian & $\begin{array}{l}-0.228 \\
(0.189)\end{array}$ & $\begin{array}{c}5.794 * * \\
(0.861)\end{array}$ \\
\hline Organization & $\begin{array}{c}-0.568 * * \\
(0.098)\end{array}$ & $\begin{array}{c}-1.614 * * \\
(0.234)\end{array}$ \\
\hline Important Job & $\begin{array}{l}-0.061 \\
(0.069)\end{array}$ & $\begin{array}{c}1.058 * * \\
(0.299)\end{array}$ \\
\hline Part-Week & $\begin{array}{l}-0.200 \\
(0.113)\end{array}$ & $\begin{array}{c}0.387 \\
(0.337)\end{array}$ \\
\hline
\end{tabular}




\begin{tabular}{|c|c|c|}
\hline Extended Care & $\begin{array}{c}0.824 * * \\
(0.110)\end{array}$ & $\begin{array}{c}-1.662 * * \\
(0.363)\end{array}$ \\
\hline Head Start & -- & $\begin{array}{c}16.868^{* *} \\
(0.722)\end{array}$ \\
\hline Before And After School & $\begin{array}{c}0.452 * * \\
(0.094)\end{array}$ & $\begin{array}{c}-1.827 * * \\
(0.256)\end{array}$ \\
\hline Summer Camp & $\begin{array}{c}0.273 * * \\
(0.085)\end{array}$ & $\begin{array}{c}0.879 * * \\
(0.251)\end{array}$ \\
\hline Evening Care & $\begin{array}{c}-0.398^{*} \\
(0.188)\end{array}$ & $\begin{array}{c}15.109 * * \\
(1.92)\end{array}$ \\
\hline Sick Care & $\begin{array}{c}0.455 \\
(0.261)\end{array}$ & $\begin{array}{l}1.568^{*} \\
(0.748)\end{array}$ \\
\hline 24-Hour Care & -- & $\begin{array}{c}-14.34 * * \\
(4.229)\end{array}$ \\
\hline Unemployment & $\begin{array}{c}-0.002 \\
(0.022)\end{array}$ & $\begin{array}{c}-0.150^{*} \\
(0.058)\end{array}$ \\
\hline Percent Subsidized & $\begin{array}{c}-1.596 * * \\
(0.177)\end{array}$ & $\begin{array}{c}-5.091 * * \\
(0.442)\end{array}$ \\
\hline Center Age & $\begin{array}{c}-0.051 * * \\
(0.005)\end{array}$ & $\begin{array}{l}-0.009 \\
(0.009)\end{array}$ \\
\hline FTE Children & $\begin{array}{c}0.005^{* *} \\
(0.001)\end{array}$ & -- \\
\hline Household Income1 & $\begin{array}{c}0.004 \\
(0.120)\end{array}$ & $\begin{array}{c}3.669 * * \\
(0.399)\end{array}$ \\
\hline Household Income2 & $\begin{array}{c}0.012 \\
(0.113)\end{array}$ & $\begin{array}{c}5.249 * * \\
(0.394)\end{array}$ \\
\hline Household Income3 & $\begin{array}{c}-0.377 * * \\
(0.116)\end{array}$ & $\begin{array}{c}2.314 * * \\
(0.329)\end{array}$ \\
\hline Household Income4 & $\begin{array}{c}0.148 \\
(0.127)\end{array}$ & $\begin{array}{l}-0.360 \\
(0.321)\end{array}$ \\
\hline Household Income5 & $\begin{array}{l}-0.228 \\
(0.143)\end{array}$ & $\begin{array}{c}0.208 \\
(0.263)\end{array}$ \\
\hline Union & -- & $\begin{array}{c}-2.898 * * \\
(0.325)\end{array}$ \\
\hline Own Kids & $\begin{array}{c}-0.124 * * \\
(0.030)\end{array}$ & $\begin{array}{c}-1.215 * * \\
(0.127)\end{array}$ \\
\hline Own Kids At Center & $\begin{array}{c}0.535^{* *} \\
(0.081)\end{array}$ & -- \\
\hline California & $\begin{array}{c}0.444 * * \\
(0.131)\end{array}$ & $\begin{array}{c}-10.525^{* *} \\
(0.844)\end{array}$ \\
\hline Colorado & $\begin{array}{c}0.050 \\
(0.131)\end{array}$ & $\begin{array}{c}-5.562 * * \\
(0.545)\end{array}$ \\
\hline Connecticut & $\begin{array}{c}0.382 * * \\
(0.146)\end{array}$ & $\begin{array}{c}-10.186^{* *} \\
(0.795)\end{array}$ \\
\hline
\end{tabular}

See the notes to Table 9 . 
Table 9

Compensation Equations

\begin{tabular}{|c|c|c|c|c|}
\hline Variable & $\begin{array}{l}\text { For-profit } \\
\text { Full-time }\end{array}$ & $\begin{array}{l}\text { Nonprofit } \\
\text { Full-time }\end{array}$ & $\begin{array}{l}\text { For-profit } \\
\text { Part-time }\end{array}$ & $\begin{array}{l}\text { Nonprofit } \\
\text { Part-time }\end{array}$ \\
\hline Constant & $\begin{array}{l}1.466 * * \\
(0.085)\end{array}$ & $\begin{array}{l}1.564 * * \\
(0.056)\end{array}$ & $\begin{array}{l}1.202 * * \\
(0.034)\end{array}$ & $\begin{array}{c}1.99 * * \\
(0.097)\end{array}$ \\
\hline Tenure & $\begin{array}{l}0.001 * * \\
(0.0002)\end{array}$ & $\begin{array}{l}0.001 * * \\
(0.0002)\end{array}$ & $\begin{array}{l}0.003 * * \\
(0.0002)\end{array}$ & $\begin{array}{l}0.001 * * \\
(0.0002)\end{array}$ \\
\hline Experience & $\begin{array}{c}0.004 * * \\
(0.001)\end{array}$ & $\begin{array}{c}0.009 * * \\
(0.001)\end{array}$ & $\begin{array}{c}0.001 \\
(0.001)\end{array}$ & $\begin{array}{c}0.002 \\
(0.002)\end{array}$ \\
\hline Other Experience & $\begin{array}{c}-0.001 \\
(0.001)\end{array}$ & $\begin{array}{c}0.001 \\
(0.001)\end{array}$ & $\begin{array}{c}0.004 * * \\
(0.001)\end{array}$ & $\begin{array}{l}0.004 * \\
(0.002)\end{array}$ \\
\hline Female & $\begin{array}{c}0.041 \\
(0.042)\end{array}$ & $\begin{array}{c}0.020 \\
(0.024)\end{array}$ & $\begin{array}{c}0.015 \\
(0.018)\end{array}$ & $\begin{array}{c}-0.152 * * \\
(0.058)\end{array}$ \\
\hline High School & $\begin{array}{c}0.025 \\
(0.057)\end{array}$ & $\begin{array}{l}-0.030 \\
(0.026)\end{array}$ & $\begin{array}{c}0.297 * * \\
(0.023)\end{array}$ & $\begin{array}{c}0.020 \\
(0.044)\end{array}$ \\
\hline Some College & $\begin{array}{c}0.001 \\
(0.056)\end{array}$ & $\begin{array}{l}-0.015 \\
(0.022)\end{array}$ & $\begin{array}{c}0.439 * * \\
(0.022)\end{array}$ & $\begin{array}{l}0.106^{*} \\
(0.046)\end{array}$ \\
\hline Community College & $\begin{array}{c}0.025 \\
(0.056)\end{array}$ & $\begin{array}{c}0.081 * * \\
(0.027)\end{array}$ & $\begin{array}{c}0.534 * * \\
(0.025)\end{array}$ & $\begin{array}{c}0.143 * * \\
(0.052)\end{array}$ \\
\hline College & $\begin{array}{c}0.166 * * \\
(0.055)\end{array}$ & $\begin{array}{c}0.078 * * \\
(0.024)\end{array}$ & $\begin{array}{c}0.475 * * \\
(0.020)\end{array}$ & $\begin{array}{c}0.099 \\
(0.055)\end{array}$ \\
\hline Some Graduate School & $\begin{array}{c}0.205 * * \\
(0.071)\end{array}$ & $\begin{array}{l}0.071 * \\
(0.031)\end{array}$ & $\begin{array}{c}0.570 * * \\
(0.028)\end{array}$ & $\begin{array}{c}0.158 * * \\
(0.06)\end{array}$ \\
\hline Graduate Degree & $\begin{array}{c}0.057 \\
(0.063)\end{array}$ & $\begin{array}{c}0.261 * * \\
(0.059)\end{array}$ & $\begin{array}{c}0.398 * * \\
(0.021)\end{array}$ & $\begin{array}{c}0.323 * * \\
(0.056)\end{array}$ \\
\hline No Training & $\begin{array}{c}-0.056^{* *} \\
(0.019)\end{array}$ & $\begin{array}{c}-0.069 * * \\
(0.019)\end{array}$ & $\begin{array}{c}0.066^{* *} \\
(0.014)\end{array}$ & $\begin{array}{l}-0.011 \\
(0.032)\end{array}$ \\
\hline White & $\begin{array}{c}0.089 * * \\
(0.028)\end{array}$ & $\begin{array}{c}0.056 \\
(0.038)\end{array}$ & $\begin{array}{c}0.109 * * \\
(0.019)\end{array}$ & $\begin{array}{c}-0.131 * * \\
(0.041)\end{array}$ \\
\hline Hispanic & $\begin{array}{c}0.027 \\
(0.032)\end{array}$ & $\begin{array}{c}0.072 \\
(0.043)\end{array}$ & $\begin{array}{l}0.060^{*} \\
(0.029)\end{array}$ & $\begin{array}{c}-0.132 * * \\
(0.046)\end{array}$ \\
\hline Black & $\begin{array}{c}0.112 * * \\
(0.034)\end{array}$ & $\begin{array}{c}0.026 \\
(0.037)\end{array}$ & $\begin{array}{c}0.082 * * \\
(0.022)\end{array}$ & $\begin{array}{c}-0.178^{* *} \\
(0.047)\end{array}$ \\
\hline Asian & $\begin{array}{l}-0.027 \\
(0.040)\end{array}$ & $\begin{array}{c}0.082 \\
(0.052)\end{array}$ & $\begin{array}{c}0.124 * * \\
(0.023)\end{array}$ & $\begin{array}{l}-0.029 \\
(0.071)\end{array}$ \\
\hline Organization & $\begin{array}{l}0.054 * \\
(0.022)\end{array}$ & $\begin{array}{c}0.056^{* *} \\
(0.018)\end{array}$ & $\begin{array}{c}0.027 \\
(0.014)\end{array}$ & $\begin{array}{c}0.049 \\
(0.028)\end{array}$ \\
\hline Important Job & $\begin{array}{c}0.003 \\
(0.014)\end{array}$ & $\begin{array}{l}-0.012 \\
(0.016)\end{array}$ & $\begin{array}{c}0.093 * * \\
(0.014)\end{array}$ & $\begin{array}{l}-0.009 \\
(0.024)\end{array}$ \\
\hline Assistant Teacher & $\begin{array}{c}-0.137 * * \\
(0.015)\end{array}$ & $\begin{array}{c}-0.166^{* *} \\
(0.012)\end{array}$ & $\begin{array}{c}-0.062 * * \\
(0.011)\end{array}$ & $\begin{array}{c}-0.158^{* *} \\
(0.023)\end{array}$ \\
\hline Infant-Toddler Room & $\begin{array}{c}-0.065^{* *} \\
(0.014)\end{array}$ & $\begin{array}{l}-0.017 \\
(0.015)\end{array}$ & $\begin{array}{c}-0.035 * * \\
(0.009)\end{array}$ & $\begin{array}{c}0.021 \\
(0.035)\end{array}$ \\
\hline On-Site & $\begin{array}{c}0.254 * * \\
(0.062)\end{array}$ & $\begin{array}{c}0.223 * * \\
(0.037)\end{array}$ & $\begin{array}{c}0.303 * * \\
(0.021)\end{array}$ & $\begin{array}{c}0.277 * * \\
(0.06)\end{array}$ \\
\hline National Chain & $\begin{array}{c}-0.050 * * \\
(0.015)\end{array}$ & -- & $\begin{array}{l}0.032 * \\
(0.013)\end{array}$ & -- \\
\hline Publicly Supported & $\begin{array}{c}-0.155^{*} \\
(0.064)\end{array}$ & $\begin{array}{c}-0.085^{* *} \\
(0.03)\end{array}$ & $\begin{array}{l}-0.076 \\
(0.053)\end{array}$ & $\begin{array}{c}0.023 \\
(0.054)\end{array}$ \\
\hline
\end{tabular}


Publicly Owned

Publicly Regulated

Religious

Union

Unemployment

FTE Children

Percent Subsidized

Center Age

Part-Week

Extended Care

Head Start

Before And After School

Summer Camp

Evening Care

Sick Care

24-Hour Care

Own Kids At Center

California

Colorado

Connecticut
(Table 9 concluded)

\begin{tabular}{|c|c|c|c|}
\hline-- & $\begin{array}{c}0.199 * * \\
(0.030)\end{array}$ & -- & $\begin{array}{c}-0.161 * * \\
(0.056)\end{array}$ \\
\hline \multirow[t]{2}{*}{-- } & $0.098 *$ & -- & 0.034 \\
\hline & $(0.045)$ & & $(0.038)$ \\
\hline \multirow[t]{2}{*}{-- } & $-0.057 * *$ & -- & $-0.079 * *$ \\
\hline & $(0.018)$ & & $(0.029)$ \\
\hline \multirow[t]{2}{*}{--} & $0.245^{* *}$ & -- & $0.211 * *$ \\
\hline & $(0.033)$ & & $(0.049)$ \\
\hline .002 & $0.012 * *$ & -0.002 & 0.007 \\
\hline .005) & $(0.004)$ & $(0.003)$ & $(0.005)$ \\
\hline $01 * *$ & 0.00001 & 0.0001 & $-0.001 * *$ \\
\hline 0001) & $(0.0002)$ & $(0.0001)$ & $(0.0003)$ \\
\hline .100 & $-0.066^{*}$ & -0.087 & -0.073 \\
\hline .055) & $(0.032)$ & $(0.053)$ & $(0.055)$ \\
\hline $002 *$ & $-0.002 * *$ & $0.007 * *$ & $0.003 * *$ \\
\hline .001) & $(0.0004)$ & $(0.001)$ & $(0.001)$ \\
\hline .040 & $-0.071 * *$ & $-0.045^{*}$ & 0.064 \\
\hline .020) & $(0.019)$ & $(0.019)$ & $(0.042)$ \\
\hline $62 * *$ & 0.030 & $0.058 * *$ & $-0.056^{*}$ \\
\hline .018$)$ & $(0.018)$ & $(0.015)$ & $(0.027)$ \\
\hline \multirow{2}{*}{--} & $-0.149 * *$ & -- & -0.112 \\
\hline & $(0.048)$ & & $(0.135)$ \\
\hline $064 * *$ & -0.005 & 0.002 & -0.010 \\
\hline .020$)$ & $(0.021)$ & $(0.015)$ & $(0.029)$ \\
\hline .001 & $0.039 *$ & $-0.066^{* *}$ & $0.124 * *$ \\
\hline .019) & $(0.018)$ & $(0.014)$ & $(0.034)$ \\
\hline $269 * *$ & $0.113 * *$ & -0.019 & 0.118 \\
\hline .042$)$ & $(0.034)$ & $(0.013)$ & $(0.092)$ \\
\hline 20 ** & 0.002 & 0.003 & -0.004 \\
\hline .075) & $(0.040)$ & $(0.027)$ & $(0.093)$ \\
\hline 170 & -- & $0.240 * *$ & -- \\
\hline 137) & & $(0.074)$ & \\
\hline .004 & 0.002 & $-0.095 * *$ & 0.064 \\
\hline .015) & $(0.021)$ & $(0.014)$ & $(0.038)$ \\
\hline $12 * *$ & $0.242 * *$ & $0.316^{* *}$ & $0.353 * *$ \\
\hline .024) & $(0.025)$ & $(0.018)$ & $(0.054)$ \\
\hline $71 * *$ & $0.054 * *$ & $0.090 * *$ & $0.105^{*}$ \\
\hline .023) & $(0.021)$ & $(0.023)$ & $(0.047)$ \\
\hline $84 * *$ & $0.303 * *$ & $0.249 * *$ & $0.370 * *$ \\
\hline .027) & $(0.031)$ & $(0.024)$ & $(0.046)$ \\
\hline 1,025 & Log-likel & ,935.89 & \\
\hline
\end{tabular}

Estimated standard errors of the coefficients are in parentheses.

* indicates statistical significance between $5 \%$ and $1 \%$.

** indicates statistical significance at the $1 \%$ level or better. 
Table 10

Selection and Heterogeneity Adjusted

Full-time and Nonprofit Wage and

Compensation Differentials

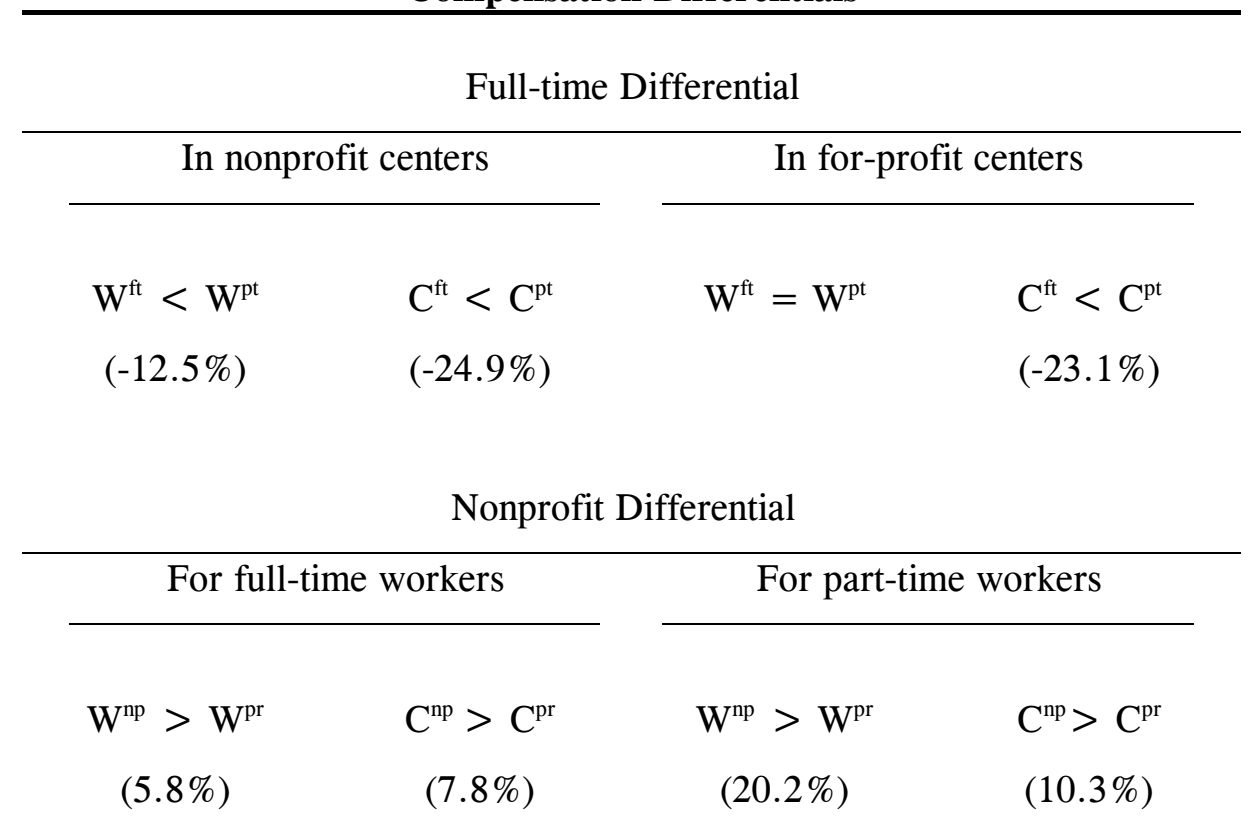

$W$ stands for wage, $C$ stands for compensation, $f t$ represents full-time, $p t$ represents part-time, $n p$ means nonprofit, and $p r$ is for-profit. Percent differences are reported in parenthesis and calculated as $\exp \left\{\mathrm{X}^{\mathrm{ft}}-\mathrm{X}^{\mathrm{pt}}\right\}-1$, or $\exp \left(\mathrm{X}^{\mathrm{np}}-\mathrm{X}^{\mathrm{fp}}\right\}-1$, where $\mathrm{X}$ is the average wage or compensation for the relevant regime from Table 10. Thus, the negative values for full-time differentials indicate that full-time wages and compensation are smaller than the corresponding part-time values. 
Table 11

1990 Census - PUMS Sample

\begin{tabular}{lcccc}
\hline \multicolumn{1}{c}{ Industry } & $\begin{array}{c}\text { Nonprofit Wage } \\
\text { Premium }\end{array}$ & $\begin{array}{c}\text { Full-time } \\
\text { Wage } \\
\text { Premium }\end{array}$ & $\begin{array}{c}\text { Number of } \\
\text { Observations }\end{array}$ & $\begin{array}{c}\text { Proportion of } \\
\text { Nonprofit } \\
\text { Workers }\end{array}$ \\
\hline Elementary and Secondary Schools & $0.104(0.005)$ & $0.286(0.006)$ & 84,635 & 0.63 \\
Colleges and Universities & $0.211(0.006)$ & $0.402(0.006)$ & 62,880 & 0.58 \\
Educational Services & $0.001(0.021)$ & $0.252(0.024)$ & 5,339 & 0.48 \\
Hospitals & $0.187(0.003)$ & $0.005(0.004)$ & 202,636 & 0.44 \\
$\begin{array}{l}\text { Savings Institutions, including } \\
\text { Credit Unions }\end{array}$ & $0.060(0.012)$ & $0.274(0.014)$ & 13,295 & 0.21 \\
$\begin{array}{l}\text { Research, Development and } \\
\text { Testing Services }\end{array}$ & $0.022(0.012)$ & $0.463(0.017)$ & 20,764 & 0.21 \\
Nursing and Personal Care & $0.115(0.006)$ & $-0.025(0.006)$ & 70.786 & 0.19 \\
Bus Service and Urban Transit & $0.154(0.020)$ & $0.120(0.014)$ & 64,908 & 0.09 \\
\hline
\end{tabular}

The dependent variable is the logarithm of wages, which is calculated as the ratio of wage or salary income divided by the product of usual hours worked per week and weeks worked. The entries are the coefficients of the nonprofit and full-time dummies. Robust standard errors are in parentheses. The regressions also include state dummies. 


\section{APPENDIX}

\section{Calculation of Compensation}

Each center provided information about the total dollar value of their nonwage benefits. Each centers also provided detailed information about 11 different benefits provided for three worker categories (teacher, assistant teachers, and part-timer) that involve monetary costs to the center. For example, centers indicated whether fully-paid or partially-paid health insurance is provided for teachers, assistant teachers and part-timers as a benefit. Other examples are at least partially paid dental insurance, paid vacations, paid maternity leave, paid health insurance for dependents, and paid sick or personal leave. For each center we counted the total number of benefits provided for each worker category. Because we know the job title and hours of work of each worker, we calculated the annual hours worked by full-time teachers, annual hours of full-time aides and annual part-time hours. Using this information and the proportion of line-item benefits provided to each group, we calculated hourly benefits that can be assigned to each group of worker. Hourly compensation for each worker is her reported hourly wage plus hourly non-wage benefits for her job category.

\section{Likelihood Function}

Conditional on the heterogeneity, the likelihood function contribution for child worker i is

$$
\begin{aligned}
& \mathrm{Li}_{\mathrm{i}}\left(\Theta \mid v_{\mathrm{j}}\right)=\left[\operatorname{Pr}\left\{\text { Profit }_{\mathrm{i}}=1 \mid v_{\mathrm{j}}\right\} \cdot \operatorname{Pr}\left\{\text { Full-time }_{\mathrm{i}}=1 \mid v_{\mathrm{j}}\right\} . \mathrm{f}\left(\mathrm{W}_{\mathrm{i}}^{\mathrm{ft}-\mathrm{p}} v_{\mathrm{j}}\right)\right]^{(\mathrm{FTi})(\mathrm{PRi})} \\
& {\left[\operatorname{Pr}\left\{\text { Profit }_{\mathrm{i}}=0 \mid v_{\mathrm{j}}\right\} . \operatorname{Pr}\left\{\text { Full-time }_{\mathrm{i}}=1 \mid v_{\mathrm{j}}\right\} . \mathrm{f}\left(\mathrm{W}_{\mathrm{i}}^{\mathrm{ft}-\mathrm{np}} \mid v_{\mathrm{j}}\right)\right]^{(\mathrm{FTi})(1-\mathrm{PRi})}} \\
& {\left[\operatorname{Pr}\left\{\text { Profit }_{\mathrm{i}}=1 \mid v_{\mathrm{j}}\right\} \cdot \operatorname{Pr}\left\{\text { Full-time }_{\mathrm{i}}=0 \mid v_{\mathrm{j}}\right\} . \mathrm{f}\left(\mathrm{W}_{\mathrm{i}}^{\mathrm{pt}-\mathrm{p}} \mid v_{\mathrm{j}}\right)\right]^{(1-\mathrm{FT} \mathrm{i})}(\mathrm{PRi})} \\
& {\left[\operatorname{Pr}\left\{\text { Profit }_{i}=0 \mid v_{j}\right\} . \operatorname{Pr}\left\{\text { Full-time }_{i}=0 \mid v_{j}\right\} . f\left(W_{i}{ }^{\text {pt-np }} \mid v_{\mathrm{j}}\right)\right]^{(1-F T i)(1-P R i)}}
\end{aligned}
$$

where $\Theta$ is the vector containing the parameters to be estimated, $f($.$) is the density function of$ the distribution in the wage equations, conditional on the unobserved heterogeneity. FT is a dummy variable for full-time work, and PR is a dummy variable for for-profit sector.

Applying the discrete factor method, and using the case with two factors $(L=2)$, each with $\mathrm{N}$ points of support in its distribution,

$$
\mathrm{Li}_{\mathrm{i}}(\Theta, \Gamma)=\sum_{l=1}^{N} \sum_{m=1}^{N} p_{1} p_{2 m} \mathrm{Li}_{\mathrm{i}}\left(\Theta \mid v_{1 l i, v_{2} m i}\right)
$$

where $\mathrm{p}_{1 l}$ is the probability that the first factor takes on the value $\mathrm{v}_{1 l}$, and $\mathrm{p}_{2 \mathrm{~m}}$ is the probability that the second factor takes on the value $\mathrm{v}_{2 m} . \Gamma$ is the vector containing the parameters of the discrete distributions ( $\rho$ 's, p's and v's). 


\section{References}

Arabmazar, Abbas, and Peter Schmidt, 1982, "An Investigation of the Robustness of the Tobit Estimator to Non-Normality," Econometrica, 50: 1055-1063.

Blanchflower, David G. and Andrew J. Oswald, 1994, The Wage Curve, MIT Press.

Blank, Rebecca M., 1990, "Are Part-Time Jobs Bad Jobs?" In Burtless, Gary, ed., A future of Lousy jobs? The Changing Structure of U.S. Wages. Washington D.C.: Brookings Institution, pp. 123-55.

Blau David M. and H. Naci Mocan, 1999, “The Supply of Quality in Child Care Centers," NBER Working Paper W7225, Cambridge.

Blau, David M. and Alison P. Hagy, 1998, "The Demand for Quality in Child Care," Journal of Political Economy, Feb, 106(1): 104-146.

Borjas, George J., H. E. Frech III, and Paul B. Ginsburg, 1983, "Property Rights and Wages: The Case of Nursing Homes." Journal of Human Resources, (18)2: 231-46.

Brown, C. and James Medoff, 1989, "The Employer size wage Effect," Journal of Political Economy, 101: 483-96.

Bureau of Labor Statistics, 2000, "Table 8: Employed and Unemployed Full- and Part-Time Workers by Age, Sex and Race," Employment and Earnings, January 2000, Washington, DC.

Evans D. S., and L. S. Leighton, 1989, "Why Do Smaller Firms Pay Less?" Journal of Human Resources, 24: 299-318.

Goddeeris John H., 1988, "Compensating Differentials and Self-Selection: An Application to Lawyers," Journal of Political Economy, 96(2): 411-428.

Goldberger, Arthur, 1983, "Abnormal Selection Bias," in S. Karlin and T. Amemiya, eds. Studies in Econometrics, Time Series and Multivariate Statistics, Academic Press: New York.

Hansmann, Henry, 1980, “The Role of Nonprofit Enterprise," Yale Law Journal, 89(5), 835901.

Harris J. and M. P. Todero, 1970, "Migration, Unemployment and Development: A TwoSector Analysis," American Economic Review 60: 126-142 
Heckman, James J. and Burton Singer, 1984, "A Method for Minimizing the Impact of Distributed Assumptions in Econometric Models for Duration Data," Econometrica, March, 52: 271-320.

Heckman, James, 1979," Sample Selection Bias as a Specification Error," Econometrica. 47, $153-62$.

Holtmann, A.G and Idson, Todd L., 1993 "Wage Determination of Registered Nurses in Proprietary and Nonprofit Nursing Homes," The Journal of Human Resources, 28(1): 55-79.

Hotchkiss, Julie L., 1991, "The Definition of Part-Time Employment: A Switching Regression Model with Unknown Sample Selection,” International Economic Review, 32(4): 899917.

Hu, WeiYin, 1999, "Child Support, Welfare Dependency and Women's Labor Supply," Journal of Human Resources, 34(1): 71-103.

Lakdawala, Darius and Tomas Philipson, 1998, "Nonprofit Production and Competition," NBER Working Paper W6377, Cambridge.

Lee, Lung-Fei, 1978, "Unionism and Wage Rates: A Simultaneous Equations Model with Qualitative and Limited Dependent Variables," International Economic Review, 19(2): 415-33.

Leete, Laura, forthcoming, "Whither the Nonprofit Wage Differential? Estimates from the 1990 Census," Journal of Labor Economics.

Main, Brian G. M. and Barry Reilly, 1992, "Women and the Union Wage Gap," The Economic Journal, 102(410): 49-66.

Mocan, H. Naci, Erdal Tekin and Jeffrey S. Zax, 2000, "The Demand for Medical Care in Urban China," NBER Working, W7673, Cambridge.

Mocan, H. Naci, 1997, "Cost Functions, Quality and Efficiency in Day Care Centers," Journal of Human Resources, 32(4): 861-891.

Mocan, H. Naci and Deborah Viola, 1997, “The Determinants of Child Care Worker's Wages and Compensation: Sectoral Difference, Human Capital, Race, Insiders and Outsiders," NBER Working Paper 6328, Cambridge.

Montgomery, Mark and James Cosgrove, 1995, "Are part Time Women Paid Less? A Model with Firm Specific Effects,” Economic Inquiry, 38: 119-133. 
Mroz, Thomas A., 1999, "Discrete Factor Approximation in Simultaneous Equation Models: Estimating the Impact of a Dummy Endogenous Variable on a Continuous Outcome," Journal of Econometrics, 92: 233-274.

Preston, Anne E., 1989, "The Nonprofit Worker in a For-Profit World," Journal of Labor Economics, 7(4): 438-63.

Preston, Anne E., 1988, "The Effects of Property Rights on Labor Costs on Nonprofit Firms: An Application to the Day Care Industry," The Journal of Industrial Economics, 36: 33750.

Rose-Ackerman, Susan, 1996, "Altruism, Nonprofits, and Economic Theory," Journal of Economic Literature, 34: 701-728.

Ruhm, Christopher and Carey Borkoski, 2000, "Compensation in the Nonprofit Sector," NBER Working Paper W7562, Cambridge.

Salamon, Lester M., Helmut K. Anheir, Regina List, Stefan Toepler, S. Wojciech Sokolowski and Associates, 1999, Global Civil Society: Dimensions of the Nonprofit Sector, Johns Hopkins Center for Civil Society Studies: Baltimore, MD.

Shackett, Joyce R. and John M. Trapani, 1987, "Earnings Differentials and Market Structure," The Journal of Human Resources, 22(4): 518-31.

Simpson, Wayne, 1986, "Analysis of Part-Time Pay in Canada", Canadian Journal of Economics, 19(4): 798-807.

Troske, Kenneth R., 1999, "Evidence on the Employer Size-Wage Premium From WorkerEstablishment Matched Data," Review of Economics and Statistics, 81(1): 15-26.

Urban Institute, Center on Nonprofits and Philanthropy, 2000, Numbers of Nonprofit Entities in the United States, 1989-1997; Washington DC.

Weisbrod, Burton A., 1983, "Non-Profit and Proprietary Sector Behavior: Wage Differentials among Lawyers," Journal of Labor Economics, 1(3): 246-263. 